\title{
A THEORY OF VICARIOUS LIABILITY
}

\section{J.W. NEYERS ${ }^{*}$}

This article proposes a theon of vicarious liability which attempts to explain the central features and Iimitations of the doctrine. The main premise of the arficle is that the common law should conimu to impose vicarious liability because it can co-exist with the current tort law regime that imposes liability for fault. The author lays out the central features of the doctrine of vicarious liability and examines why the leading rationales (such as control, compensation. deterrence, loss-spreading, enterprise liability and mixed policy) fail to explain or accoun for its doctrinal rules.

The author offers an indemnity theory for vicarious liability and examines why the current rules of vicarious liability are limited in application 10 employer-employee relationships and do not extend further. It is proposed that the solution to the puzsle of vicarious liability rests within the contractual relationship between employer-employee and not the relationship between the employer and the tort victim. The proposed indemnity theory implies a contract term that indemnifies the employee for harms suffered in the course of his or her employment. Vicarious liability then follows from an application of the contractual concepts of subrogation and indemnity to the particular relationship benween employee. employer and tort victim. Finally, the article discusses and attempts to resolve the possible criticisms that may follow she indemnity theory. including concerns that it is in conflict with leading decisions, including Lister v. Romford. Bazley v. Curry and Morgans v. Launchbury.
Cet article propose une theorie de la responsabilite du fait d'autrui qui essaie d'expliquer les caractéristiques et les timilations centrales de la doctrine. La principale prémisse de cet article est que la "common law "doit contimuer à imposer la responsabilité du fail d'autru parce qu'elle peut coexister avec le regime actuel de la responsabilité délictuelle qui impose la responsabilité pour faute. $L$ auteur enonce les caractéristiques centrales de la doctrine de la responsabilité du fait d'autrui ef examine les raisons pour lesquelles les principaux motifs (comme le controle, Iindemnisation. la dissuasion. l'étalement des pertes. la responsabilití dentreprise et la police mixte) ne peuvent $n$ expliquer ni justufier les règles de cefle doctrine.

$L$ 'auteur propose une thérie des indemniles pour la responsabilite du fait d'autrui, et examine pourquoi les règles actuelles de celte responsabilité se limilent. dans leur exécution. anx relations employeur. employé, sans aller au-delà. On suggère que la solution à ce problème réside dans les relations contractuelles entre employeur et employe at non pas dans la relation qui existe entre lemploye et la victime de la faute. La théorie des indemnités suggérie implique une condifion contractuelle qui indemniserait l'employe' des torts subis pendam la durie de son emploi. La responsabilite du fail d'autrui découlerait alors de l'exécution de concepts contractuels. à savoir la subrogation el / indemnnté à l'égard de la relation spécifique entre l'emplojé. lemployeur et la victime de la faute. Enfin. I article étudie et cherche à régler la critique èventuelle qui peut faire suite à la théorie des indemnités. incluant les préccupations à l effel qu'elle est en confli avec les principales décisions, incluam l.isler c. Romford. Bazley c. Curry et Morgans c. Launchbury.

\section{TABLE OF CONTENTS}

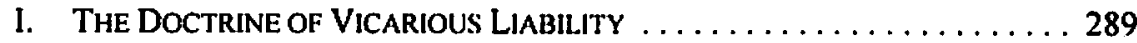

II. THE Fallure of Proposed Rationales to

EXPLAIN THE DOCTRINE . . . . . . . . . . . . . . . . . . . . . 29I

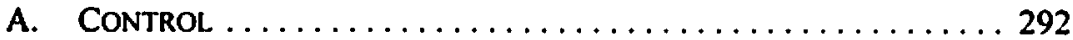

Assistant Professor of Law, University of Western Ontario. An earlier version of this article was presented to the Ton Law section of the 2004 SLS Conference in Sheffield. The author would like to thank the participants in that section for their helpful questions and suggestions. The author would also like to thank Vaughan Black. Rande Kostal, John Murphy, Stephen Pitel. Eoin Quill, Lionel Smith and Robert Stevens for their comments on earlier drafts of this article. The usual disclaimer applies. 


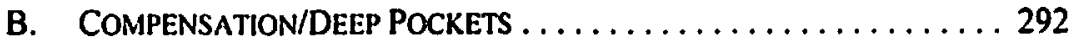

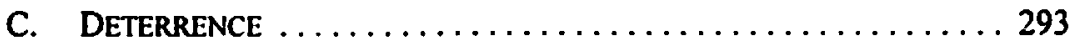

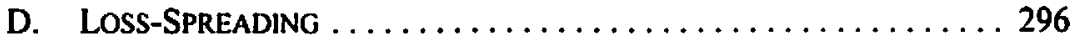

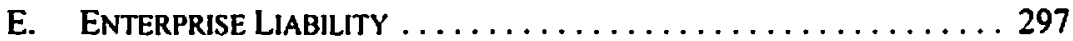

F. MIXED POLICY ........................ 300

III. AN EXPLANATION OF VICARIOUS LIABILITY .............. 30 I

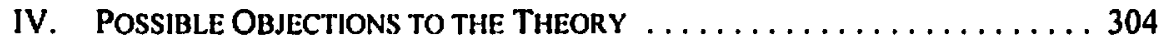

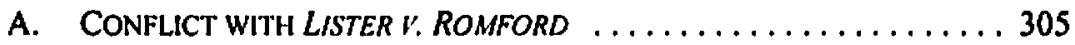

B. VICARIOUS LIABILITY AS A RULE OF LAW ........... 311

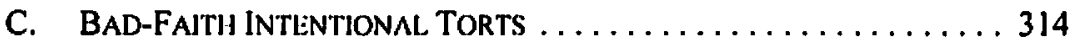

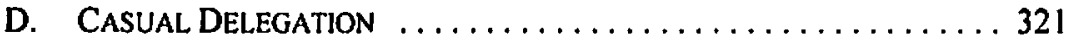

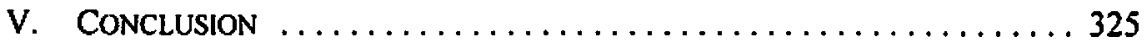

Vicarious liability occupies a mysterious place in the common law. Our system of wrongs is premised upon fault as justifying why the apparatus of the state is to be marshalled against the assets of one person for the benefit of another.' Yet despite this general conception, the law has recognized for centuries that in some cases one person may be vicariously liable for the fault of another. ${ }^{2}$ Rather than excising this anomaly on its march towards modernity, as had been suggested by some, ${ }^{3}$ the common law continued to develop and rely on vicarious liability to such an extent that it is now generally assumed that any complete theory of tort law must be able to account for its presence. ${ }^{4}$ Interestingly, this consensus has emerged in spite of the absence of any comprehensive theory of vicarious liability - a theory that actually explains the central features and limits of the doctrine. ${ }^{s}$

See e.g., O.W. Holmes, "Agency" (1890-91) 4 Harv. L. Rev. 345; (1891-92) 5 Harv. L. Rev. I at I4: "I assume that common-sense is opposed to making one man pay for another man's wrong, unless he actually has brought the wrong to pass according to the ordinary canons of legal responsibility." See also Frederic Cunningham, "Respondeat Superior In Adniralty" (1905-06) 19 Harv. L. Rev. 445 at 445 : "That there could hardly be greater injustice than to take $A$ 's property and give it to $B$ because $C$ has injured B seems clear. yet that is the result of the maxim respondeat superior." See the discussion of various common law and civilian legal systems in Lewis $v$. The Salisbury Gold Mining Co. (1894), I O.R. I (H.C.J. S.Afr.) at 20.

Sec e.g. T. Baty. V'icarious liabilin: A Short Histony of the Liabiliny of Employxes. Principals. Partners. Associations and Trade-Union . Members, (Oxford: Clarendon Press. 1916).

See Gary T. Schwartz. "The Hidden and Fundamental Issue of Employer Vicarious Liability" (1996) 69 S. Cal. L. Rev. 1739 at 1745: "IT]here is now a consensus among those ... who think aboul tort law" that vicarious liability is an essential clement in the tort system. Any idea of repealing vicarious liability would seem to us preposicrous, inconceivable." For a similar view, see W. V.H. Rogers. Winfield and Jolowicz on Tort, 16th ed. (London: Sweet \& Maxwell, 2002) at 704 [Rogers, Winfield and Jolowicz]: "It is inconceivable that a serious proposal for the abolition of vicarious liability will be made so long as the law of tort as we know it remains alive": Lewis N. Klar, Tort Law', 3rd cd., (Toronto: Thomson Carswell, 2003) [Klar, Tort Law] at 582: "Despite its inadequacies, the doctrint of vicarious liability is firmly entrenched in ... lort law."

s See New South Wales v. Lepore (2003), 195 A.L.R. 412, [2003] HCA 4 at para. 106. Gaudron J. [Lepore]:

The absence of a satisfactory and comprehensive jurisprudential basis for the imposition of liability on a person for the harmful acts or omissions of others - vicarious liability, as it is called - is a matter which has provoked much comment... Further. it may be that the failure to identify a jurisprudential basis for the imposition of vicarious liability has resulted in decisions which are not ensily reconciled with fundamental legal principle.

See also the comments of the majority in Hollis v. Vabu Po. Led. (2001), 207 C.L.R. 21. [2001] HCA 44 at para. $35[\mathrm{Vabu}]$ that "[a] fully satisfactory rationale for the imposition of vicarious liability ... has been slow to appear." 
The purpose of this article will be to unravel the mystery of vicarious liability by offering just such a comprehensive explanation of the doctrine. The article will be divided into four parts. Part I will lay out the central features of vicarious liability that need to be explained. Next, Part II will show why the leading rationales fail to adequately account for these rules. Part III will then offer a theory of vicarious liability and demonstrate that it can explain these doctrinal limitations. ${ }^{6}$ Finally, Part IV will address possible criticisms of the proposed theory. The ultimate conclusion of this article will be that the common law was right to maintain vicarious liability in the face of its criticism since the doctrine can sit comfortably beside a regime that imposes liability for fault.

\section{THE DOCTRINE OF VICARIOUS LIABILITY}

Vicarious liability is a liability that is imposed on one person (B) for the torts of another (A) in situations where B has not committed any legal wrong.' While the historical or jurisprudential origins of this liability are not entirely clear, ${ }^{8}$ it has been well entrenched in the common law for several centuries. The central features of the doctrine of vicarious liability are four-fold. First, a tort must have been committed by $A$, it not being enough that A's actions merely had an adverse impact on the plaintiff.' Second, at the relevant time, A must be an employee or agent of B. ${ }^{10}$ Third, A's tort must be committed in the course of A's

- For the sake of clarity, the theory which will be presented is not historical since, as Lord Clyde notes: "It is not useful to explore the historical origins of the vicarious liability of an employer in the hope of finding guidance in the principles of its modern application" (Lister v. /lestey/lall, [2002] 1 A.C. 215. [2001] UKHL, 22 at para. 34 (lisser v. Hesley Hall]). Nor does my argument depend on proof of a major conspiracy among hundreds of judges over hundreds of years lo secretly apply the proposed theory while publicly anticulating different justifications. Instead the argument will be that although the judges have not agreed on their reasons for imposing vicarious liability they were mostly correct in doing what they have done on the basis of a rationale that never occurred to them. t.e. the one presented in Pant III of this article.

7. As was noted by the Privy Council in Bernard v. The Altorney General of Jamaica, [2004] UKPC 47 at para. 2 (BAILII), Lord Steyn: "Vicarious liability is i principle of strict liability. It is a liability for a tort committed by an employee not based on any fault of the employer. There may, of course, be cases of vicarious liability where employers were at fault. But it is not a requirement. This consideration underlines the need to keep the doctrine within clear limits."

* Oliver Wendell Holmes suggested the doctrine was based on the fiction that the act of the servant is the act of the master: see Holmes, supra note I. Wigmore argued that the doctrine arose out of the liability of the employer for commands given to his servants within the course of the servant's employment: John H. Wigmore, "Responsibility for Tortious Acts: Its History" (1893-94) 7 Harv. L. Rev. 315 [Wigmore]. For judicial elaboration of the history of vicarious liability: see British Columbia Ferry Corp. v. Invicla Security Service Corp. (1998), 167 D.L.R. (4th) 193 (B.C.C.A.) al para. 12.

- At one time, under the master's tort theory, it was thought that a tort did not necessarily have to have been committed by the cmployee, see Twine v. Bean is Express Lid. [1946] I All E.R. 202 (C.A.): Broom v. Morgan. [1953] I Q.B. 597 (C.A.): and the discussion in Glanville Williams, "Vicarious Liability: Tort of the Master or of the Servant?" (1956) 72 Law Q. Rev. 522. This line of reasoning was replaced by the now orthodox servant's tort theory adopted in Staveley Iron and Chemical $C o$. Lid. $v$. Jones. [1956] A.C. 627 (H.L.) |Siaveley] and Imperial Chemical Indisires v. Shaniell. [1965] A.C 656 (H.L.).

11 See e.g. MacDonald v. Advocate General for Scotland and Pearce v. Mayfield Secondany School Governing Body, [2004] I All E.R. 339. [2003] UKHL. 34. While there has been controversy and confusion us to whether the law accepts a general regime of vicarious liability of principals for the lorts of their agents (see P.S. Atiyah, Vicarious Liability in the Lenr of Torts (London: Butterworths, 1967) at c. 9; and F.M.B. Reynolds et al., Bowstead \& Reynolds on Agency, 17th ed. (London: Sweet \& Maxwell, 2001) at 21-22 [Reynolds. Bowstead \& Rejnolds]), it is submitted that the law is best summarized by G.H.L. Fridman, The Law of Torts in Canada, 2d cd. ('oronto: Carswell, 2002) at 292 
employment with B." And finally, the fact that B also is liable for A's tort does not insulate $A$ from liability - i.e. A and $B$ become joint tortfeasors both amenable to suit by the tort victim. These are the central features for which any theory of vicarious liability will have to be able to account. ${ }^{12}$

In order to be a complete explanation of vicarious liability, however, it is not enough to explain these elements of the doctrine. A comprehensive theory of vicarious liability will also have to explain why the private law doctrine is limited in its application solely to the employer-employee relationship. ${ }^{3}$ Thus, it will have to explain why vicarious liability is not

[Fridman, Torts in Canada]:

In the modern law of vicarious liability there appears to be no reason to differentiate an agent who is employed by a principal for the purpose of negotiating contracts on his behalf from a servant whose functions are associated less with the transaction of legal business than with the performance of non-legal acts on his master's behalf. Older law referred to a principal's liability for torts committed by his agent in terms of whether they were committed while the agent was acting within the scope of his authority, and to a master's liability for torts committed by his servant in terms of whether such acts were performed by the servant while he was acting in the course of his employment. The expressions "scope of authority" and "course of employment" have now become indistinguishable. They are in effect interchangeable. Courts regularly speak of an act with in or outside the course of employment. or the scope of authority, of an employee, whether such employee is an agent in the restricted sense, or a servant as that term was meant in earlier centuries.

See also, Thomas Atkins Streel. The Foundations of Legal Liability: A Presentation OfThe The ory and Development of the Common Lans: vol. 2 (Nonhport, N.Y.: Edward Thompson, 1906) at 454: Anthony M. Dugdale ed.. Clerk \& Lindsc/l on Torss. 18th ed. (London: Sweet \& Maxwell, 2000) at 262 [Dugdale, Clerk \& Lindsell]: Ileatons Transport (SI. Helens) Lid. v. Trunsport and General Workers Union, [1973] A.C. 15 (H.L.), L.ord Wilberforce. The only limitation on the statement given by Fridman is that in order for a principal to be liable for the torts of a true agent it must be demonstrated that the agent was not in fact an independent contractor; see infra, note 14 and Atiyah, earlier in this note at $347-48$.

11 For ease of reference, this article will henceforth use language which refers to the employee-tmployer relationship, wherever possible, which should be taken to include the principal-agent relationship as well.

: For a description of these features, see Dugdale, Clerk \& Lindsell, supra note 10 at 233-34; Rogers, Winfield and Jolowics. supra note 4 at 701-703; B.S. Markesinis et al. Markesinis and Deakin 's Tort Law (New York: Oxford University Press. 2003) at 572 [Markesinis, Markesinis and Deakin]: Tony Weir, Torı Law (Oxford: Oxford University Press, 2002) at 95: Nicholas J. McBride \& Roderick Bagshaw, Tort Law. 2d ed. (Harlow: Longman, 2005) at 634-37; Francis A. Trindade \& Peter Canc. The Law' of Toris in Australia, 3d ed. (Melboume: Oxford University Press, 1999) al 717, 735, 742. Klar, Tort Law, supra note 4 at 579-80, 586; Fridman, Toris in Canada, supra note 10 at 276; M.A. Jones, Textbook on Torts, 81h ed. (Oxford: Oxford University Press, 2002) al $421 \mathrm{~m}$.

1" Vicarious liability is also statutorily imposed in various Commonwealth countries, for example, on partners for the torts of their partners. on the heads of police forces for the torts of their officers, and on the Crown for the torts of its servants. These statutory manifestations of vicarious liability are not discussed in this article (though it is likely that these manifestations of vicarious liability are also explicable on the theory herein proposed). It is also sometimes stated, on the authority of Brooke v. Bool, [1928] 2 K.B. 578 (Div. Ci.) that parties are vicariously liable for the torts of their joint venturers: see McBride \& Bagshaw, stupra note 12 at 637 . This blanket statement is somewhat misleading. In some cases, true vicarious liability is imposed, not due to the parties status as joint venturers but rather because the parties, much like those participating in a partnership, can be viewed as mutual agents, see Co-operative Retail Services LId. v. Taff-Ely Borough Council, [1983] 133 N.L.J. 577 (Q.B.). Beldam J. In other situations where the agency interpretation is unavailable, liability is fault-based since the apparently faultless joint venturer procured, authorized or conspired to commit a tort, breached a non. delegable duty or was personally negligent: see Hazel Carty, "Joint Tortfeasance and Assistance Liability" (1999) 19 L.S. 489 for a discussion. Some of the misunderstanding surrounding this area of the law has been engendered by Brooke' $v$ Bool itself since the two judges who decided the case offered 
imposed on employers for the torts of their independent contractors, ${ }^{14}$ on parents qua parents for the torts of their children, ${ }^{15}$ on superior servants for the torts of their subordinates, ${ }^{16}$ on beneficiaries for the torts of their trustees, ${ }^{17}$ nor on shareholders for the torts of company directors/employees. More generally, it will have to explain why the common law's commitment to strict liability in the employer-employee relationship has not led to the adoption of a comprehensive regime of strict liability in tort. ${ }^{18}$ In other words, it will have to explain where vicarious liability begins but also why it stops where it does. As Allan Beever notes:

In recommending a [rationale], the task is not merely to show that the favoured [rationale] generates the desired outcome in the particular situation under discussion: it is also to show that the [rationale] does not generate inappropriate outcomes in other situations. But the latter seldom receives attention. ${ }^{19}$

\section{The fallure of Proposed Rationales to Explain the Doctrine}

This part of the article will examine the leading rationales put forth to justify vicarious liability and argue that none of them are true explanations of the doctrine since they cannot

at least four different justifications for liability on its facts including: agency. control. joint enterprise and breach of non-delegable duty. This over determination and lack of clarity may explain why the case "has engendered curiously little in the way of subsequent reported authority": see Unilever Plc v. Gillette (U.K.) Lid., [ 1989] R.P.C. 583 (C.A.) at 603. Mustill L.J. In any event, if the foregoing analysis is correct, the existence of liability for joint venturers is perfectly consistent with the theory of vicarious liability that will be proposed in Part III of this anticle.

11 Quarman v. Burnell (1840). [1835-1842] All E.R. Rep. 350, I5I E.R. 509 (Ex. Ct.); Sievens v. Brodribb Sawmilling (1985), 160 C.L.R. 16 (H.C.A.): $D$ is F E.states l.td. v. Church Commissioners for Eingland, [1989] A.C. 177 (H.L.): Northern Sandblasing Poy L.d. v. Marris (1997). 188 C.L.R. 313 (H.C.A.) [Northern Sandblasting]; 67I122 Ontario Lad. v. Sagaz Industries Canada Inc., [2001] 2 S.C.R. 983, 2001 SCC 59 |Sagaz|. While some texts (set Atiyah, supra note 10 at 3: Trindade \& Cane. supra note 12 at 739; Fridman. Torts in Canada, supra note 10 at 309-10) contend that in some circumstances there is such vicarious liability, when these situations are examined it can be seen that the instances of liability are all manifestations of personal liability, usually in the form of a breach of some kind of non-delegable duty. For a similar view, see Dugdale, Clerk \& Lindsell, supra note 10 at 250: Rogers, Winfield and Jolowicz, supra note 4 at 729: Mel3ride \& Bagshaw, supra note 12 at 636; Jones, stupra note 12 at 440.

Moon v. Towers (1860), 8 C.B. (N.S.) 6II, 14I E.R. 1306 (C.P.); Carmarthenshire CC v. Lewis. [1955] A.C. 549 (H.L.). Parents can, however, be held vicuriously liable qua employer/principal if their children commil a tort while acting the course of their employment or agency: Simith v. Leurs (1945). 70 C.L.R. 256 (H.C.A.): Hewill v. Bonvin. [1940] I K.B. 188 (C.A.). But this, of course, is just an application of the ordinary rules of vicarious liability. Bainbridge v. Postmaster General, |1906] I K.B. 178 (C.A.): Rainbou' Industrial Caterers Lad. v. C.N.R. Co. (1998), 54 D.L.R. (4th) 43 (B.C.C.A.).

1 In certain limited circumstances, a beneficiary will become liable to personally indemnify a trustee for her torts and hence become vicariously liable for them. Put crudely, this occurs when a trustee has become an agent of an absolutely entitled beneficiary: see Hardoon v. Belilios. [1901] A.C. 118 (P.C.): Trident Itoldings Lid. v. Danand Investments L.td (1998), 64 O.R. (2d) 65 (C. A.): Reynolds, Bow'slead \& Reynolds, supra note 10 at 20 . For a detailed discussion. see John Mowbray el al., Lewin on Trusts. 17th ed. (London: Sweet \& Maxwelt, 2000) c. 21. Once again, however, this is just an application of the ordinary rules of vicarious liability.

in As Ernest Weinrib argues: "A justification justifies: it has normative authority with respect to the material to which it applies. The point of adducing a justification is to allow that authority to govern whatever falls within its scope. Thus if a justification is to function as a justification, it must be permitted, as it were, to expand into the space that it naturally fills." See Ernest J. Weinrib, The Idea of Private Law, (Cambridge: Harvard University Press. 1995) at 39 [Weinrib. Private Law]. 
explain the central features of the doctrine nor its doctrinal limits. This argument will not be exhaustive since many of the arguments have been made in detail before and only limited argument is necessary to show that the leading theories of control, compensation, deterrence, loss-spreading, enterprise liability and mixed policy fail adequately to explain the existing limitations of the doctrine. ${ }^{20}$

\section{A. CONTROL}

One of the traditional explanations of vicarious liability is that the employer should be vicariously liable since the employer controls the activities of her employees. ${ }^{21}$ Unfortunately, control cannot explain the contours of vicarious liability for a number of reasons. As was noted eloquently by P.S. Atiyah.

control cannot be treated as either a sumicient reason for always imposing liability, or as a necessary reason without which there should never be vicarious liability. Control has never per se been a ground for imposing vicarious liability, e.g., a parent is not liable for the tons of his children, a superior servant is not liable for the torts of subordinate servants. schoolteachers are not liable for the torts of their pupils and so forth. Conversely the absence of control - although at one time thought to preclude vicarious liability in the case of skilled and professional servants - is today not a serious obstacle to such liability. ${ }^{22}$

Thus, given these failings, control is an inadequate explanation of the present contours of vicarious liability.

\section{B. COMPENSATION/DEEP POCKETS}

The compensation explanation of vicarious liability holds that the rationale for the doctrine is to ensure that innocent plaintiffs have a solvent defendant against whom to enforce their legal rights and that as between employees and employers this is most likely to be the employer who is wealthier and/or carries insurance. ${ }^{23}$ This justification of vicarious liability is flawed for three primary reasons. First, it does not explain why compensation must come from the employer, since the plaintiff would be equally well compensated if the

As Weir, supra note 12 at 96 argues: "There is no point in discussing the matter ... [since] the scope of the rule is not determined by the preferred rationale." I have not included discussion of the maxims respondeat superior and quifacit per alium facit per se since they are generally discredited as theories of vicarious liability, sec e.g., John G. Fleming. The Law of Torts, 9th ed. (Sydney: LBC Information Services, 1998) at 410; Fridman. Torts in Canada, supro note 10 at 277.78. As Lord Reid observed in Staveley, supra note 9 at 643: "The former merely stalts the rule baldly in two words, and the latter merely gives a fictional explanation of it."

2: Atiyah ibid. at 16. See the similar comments regarding children in Baty ibid. at 153.

" See Limpus v. London General Omnbus Company (1862), 158 E.R. 993 at 998, Willes J.: "It is wellknown that there is virtually no remedy against the driver of an omnibus, and therefore it is necessary that, for injury resulting from an act done by lim in the course of his master's service, the master should be responsible; for there oughte to he a remedy against some person capable of paying damages to those injured by improper driving." Sec also Viscount Canterbury v. A. -G. (1842), I Ph. 306. Lord Lyndhurst L.C.: Bazley v. Curry, [1999] 2 S.C.R. 534 at para. 30 [Bazley]; Baty. supra note 3 at 154; Fleming. supra note 20 at 410 : Bruce Feldthusen, "Vicarious Liability For Sexual Torts" in Nicholas J. Mullany \& Allen M. Linden, eds.. Torts Tomorron: A Tribuse to John Fleming (Nonth Ryde. N.S.W.: LBC Information Services. 1998) at 224-25. 
payment came from any other source. ${ }^{24}$ Moreover. even if the concern is "effective compensation"2s as opposed merely to "possible compensation," the government, in most cases, has deeper pockets than any employer. ${ }^{26}$ Second, the compensation explanation, when taken seriously, also tends to destroy the employee/independent contractor distinction. As Robert Flannigan argues: "Generally speaking, an employer will be richer ... than the workers he employs, whether they are servants or independent contractors. That being so ... no distinction ought to be made between servants and independent contractors for the purposes of vicarious liability." 27 Third, the compensation rationale cannot explain why the plaintiff must have suffered a tort at the hands of the employee or why this tort must have been committed in the course of employment. ${ }^{28}$ As Ernest Weinrib notes: "Behind the identification of compensation as a goal of tort law is the need created in the victim by the very fact of injury. This need, however, is unaffected by the way the injury was produced." 29 Thus, since the rationale of compensation cannot explain why the compensation must come from the employer, nor justify three of the central doctrinal requirements of the law of vicarious liability, it cannot be a persuasive explanation of the doctrine.

\section{DETERRENCE}

The deterrence explanation of vicarious liability comes in two broad forms: one focused on the employer; the other focused on the employee. The employer-focused version of the theory argues that since larger economic units are in the best position to reduce accidents through efficient organization and discipline of staff, the law is justified in making them

Emest J. Weinrib, "Understanding Tort Law" (1989) 23 Val. U.L. Rev. 485 at 503-505. As Roben Flannigan questioned: "Why ... is the choice of compensator only a choice between the employer and the servant?" Robert Flannigan, "Enterprise Control: "The Servant-Independent Contractor Distinction" (1987) 37 U.T.L.J. 25 at 28. See also Lewis N. Klar. "Judicial Activism in Private Law" (2001) 80 Can. Bar Rev. 215 at 237 [Klar. "Judicial Activisı"].

3 Bazley, supra note 23 at para. 31.

3. Likewise, see Atiyah, supra note 10 at 22, who notes:

After all there will atways be plenty of people in the world better able to pay damages than any particular defendant who may be unfortunate enough to be sued for a tort. but mere wealth. however good a ground it may be for imposing taxation. could never by itself be treated as a ground for imposing liability in ton. And even if it were. Why should the employer out of all the other wealthy people in the world he singled out lor liability? Clearly this justification is no justification at all.

For a similar view: see Christopher G. Riggs, "Vicarious Liability of Employers For Sexual Abuse By Employees: Implications For Churclies of Recent Judicial Decisions" (2000) 3 J. of Church L. Assoc. Can. 87 at 101: Flannigan, supra note 24 at 28-29.

27 Flannigan, supra note 24 at 28 . For a similar vicw, see the judgment of Waller L..J. in Gwilliam v. West Hertfordshire Hospital NHS Trust, [2003] Q.B. 443 (C. A.) at para. 38 where he attempted to create a duty on the employer of an independent contractor to ensure not only the salely of an independent contractor but also the collectibility of any award made against it. This broad duty was doubted in Naylor v. Payling. [2004] EWCA Civ. 560.

2* See Atiyah, supra note 10 at $27-28$ : "Undoubtedly it would be just as convenient and efticient a method of securing compensation for aecidents to make all employers pay for their servants ${ }^{\circ}$ torts, and therefore to insure against them, when they are committed outside the servant's course of his employment, as much as when they are committed within the course of employment." Ste also. McBride \& Bagshaw. supra note 12 at 638; Trindade \& Cane, supra note 12 at 736

* Weinrib. Private Lav. supra note 18 at 38. For a similat view, see Peter Canc. The Anatomy of Tort Law' (Oxford: Hart Publishing, 1997) at 47 [Cane. Anatomy] (the compensation "argument cannot explain why vicarious liability is more or less limited in its application to the employer-employec relationship and why tort law is not generally based on social wellarist principles.") 
vicariously liable in the name of accident reduction. ${ }^{30}$ This version of the deterrence argument is not really an explanation of vicarious liability, however, since it either negates the "vicarious" aspect of the rule or it is over-inclusive and cannot explain why it is limited to the employee/employer relationship.

If the reason for vicarious liability is that the employer should be held liable because she committed some fault (such as failing to supervise, foster a proper environment or select appropriately) then liability is not vicarious but rather a particular application of the fault regime." Moreover, if this was the reason for the rule, then one would expect that the employer would be able to escape from "vicarious" liability by proving that she was without fault (as one is able to do in the German version of the doctrine). ${ }^{32}$ However, as is well known, positive proof that the employer conducted herself without fault will not serve as a defence to the common law version of the doctrine. ${ }^{33}$ For these reasons, therefore, this version of the employer-focused deterrence rationale cannot explain vicarious liability.

Some versions of the employer-focused deterrence argument, however, are not dependent on the employer's fault but rather argue, as the Supreme Court of Canada did in Bazley, that

[b]eyond the narrow band of employer conduct that attracts direct liability in negligence lies a vast area where imaginative and efficient administration and supervision can reduce the risk that the employer has introduced into the community. Holding the employer vicariously liable for the wrongs of its employee may encourage the employer to take such steps, and hence, reduce the risk of future harm. ${ }^{34}$

While this might be a valid reason to hold someone liable in the abstract, the theory cannot explain why this liability is not imposed across the private law - in other words why liability for preventable yet not reasonably foreseeable harms is limited to the employee-employer relationship. ${ }^{35}$ For example, on this analysis, there is no reason why the defendant in Bolion v. Stone should not have been held liable to compensate the plaintiff for the foreseeable and preventable, but not reasonably foreseeable, injuries that she suffered since "imaginative and efficient administration" might have reduced the risk of her injury. ${ }^{36}$ Thus, since the

See Fleming, supra note 20 at $\mathbf{4 1 0}$. For a slightly different view, see Peter Cane, "Responsibility and Fault: A Relational and Functional Approach to Responsibility" in Peter Cane \& John Gardner, eds., Relating 10 Responsibility (Oxford: Hart Publishing. 200I) 81 at 100 ("an important justification for strict liability is to increase the chance that those at fault will be held liable in the face of difficulties of proof").

" See e.g., Mantis v. Pollock, [2003| 1 W.L.R. 2158 (C.A.) where the fault of the employer in encouraging employec violence may explain the court's decision to impose "vicarious" liability. For a discussion of the case, see Robert Weeks, "Vicarious Liability for Violent Employees" (2004) 63 Cambridge L.J. 53. See Basil Markesinis \& Hannes Unberath. The German Lan' of Torts, 4th ed. (Oxford: Hart Publishing. 2002) at 700.

"See Atiyah, supra note 10 at 19: "It is, of course, as clear as anything could be that the master is not exonerated from liability mercly because he has exercised all possible care in his choice of servam. "See also, Baty, supra note 3 at 147: Glanvilie Williams, "Vicarious Liability and the Master's Indemnity" (1957) 20 Mod. L. Rev. 220, 20 Mod. L. Rev. 437 at 438 [Williams. "Master's Indemnity"]. See Bazley, supra nole 23 at para. 33. See also London Drugs Lid. v. Auelme \& Nagel International Lid. [ [1992] 3 S.C.R. 299 at 339. La Forest J. [London Drugs].

" For a similar point, see Klar. "Judicial Activism," supra note 24 at 237

4. [1951] A.C. 850 (H.L.). See especially the speech of Lord Radcliffe who stated at 868: "I can see nothing unfair in the appellants being required to compensate the respondent for the serious injury that she has received as a result of the sport that they have organized on their cricket ground at Cheetham 
employer-centred version of deterrence is either a form of fault or posits a systematic form of strict or "quasi-fault" liability that is logically illimitable to the employee-employer relationship, this form of the deterrence argument cannot explain vicarious liability.

The employee-centred version of the deterrence rationale argues that since employees rarely have sufficient wealth to meet the full costs of their liabilities and in some circumstances it will not be possible for the tort victim to identify the particular employee responsible, employees will be inadequately deterred from committing torts. In order to meet this deterrence gap, employers are held vicariously liable since employers can often take measures to influence employee behaviour through discipline at work or through the ultimate penalty of dismissal. ${ }^{37}$

While this may appear to offer some explanation of vicarious liability there are a number of problems with this version of the deterrence rationale. First, in many situations the identity of the employee/tortfeasor will be known ${ }^{38}$ and even in situations where the identity might be unknown there are many procedural and evidentiary devices, short of vicarious liability, that can be used to encourage those with information to disclose what they know. ${ }^{30}$ Second. the deterrence theory does not work particularly well where the act to be deterred is already a crime. ${ }^{* 0}$ As Gummow and Hayne JJ. noted in Lepore: "If the criminal law will not deter the wrongdoer there seems little deterrent value in holding the employer of the offender liable in damages for the assault committed." 41 Third, the theory cannot explain why damages are paid to the injured plaintiff, since the employer would be equally induced to monitor her employee if damages were paid to the state or any other person. ${ }^{42}$ Fourth, the rationale does

Hill. But the law of negligence is concerned less with what is tair than with what is culpable, and I cannot persuade myself that the appellants have been guilty of any culpable act or omission in this case."

" See Kevin E. Davis, "Vicarious L iability, Judgment Proofing and Non-Profits" (2000) 50 U.T.L.J. 407 at 409-11 summarizing the main thrust of the American deterrence literature such as Steven Shavell, Economic Analysis of Accident Law (Cambridge: Harvard University Press. 1987) at 173: Alan O. Sykes, "The Economics of Vicarious Liability" (1984) 93 Yale L.J. 1231: Alan O. Sykes. "The Boundaries of Vicarious Liability: An Economic Analysis of the Scope of Employment Rule and Related Legal Doctrines" (1988) I0I I larv. L. Rev. 563; Steven P. Croley. "Vicarious Liability in Tort On the Sources and Limits of Employee Reasonableness" (1996) 69 S. Cal. L. Rev 1705: Bruce Chapman, "Corporate Ton Liability and the Problem of Overcompliance" (1996) 69 S. Cal. L Rev. 1679. See also Jennifer H. Arlen \& W. Bently Macleod. "Beyond Master-Servant: A Critique w" Vicarious Liability" in M. Stuart Madden, ed., Exploring Tort Lan (Cambridge: Cambridge University Press, 2005) 111.

Schwartz. supra note 4 at 1756 argued: "[I]t is only a small subset of cases in which an tunployec pondering negligent conduct can appreciate that his identity will remain beyond the ken of the plaintiff."

24 As Richard Townshend-Smith argued, many of these problems could be overcome by reversing the burden of proof by assuming that a tort committed by an employee was exacerbated by the negligence of the employer and then leaving it up to the emplojer to prove that she was not at fault. ste $R$ Townshend-Smith, "Vicarious Liability for Sexual (and other) Assaults" (2000) 8 Torl L. Rev. I(1) all 128.

4t As was the case in many of the recent leading cases. such as Basley, supra note 23: Lisfer v. Ifesley Mall, supra nole 6; Lepore. supra note 5, efc.

$\$ \quad$ Lepore, supra note 5 at para. 219. For a similar view: see Riggs. supra note 26 at 101 where he arguts "-[I]n the case of sexual predators who are detered neither by potential criminal sanclions nor efliciciut administration of a church's affairs. the imposition of liability on the church - whatever its ratıonale - will bear little relationship to deterrence." 
not seem to limit itself to the employee-employer relationship. Many, if not most, people would be unable to meet any major tort claim made against them ${ }^{43}$ and thus, the deterrence theory would point to a generalized vicarious liability regime for the types of torts which are inadequately deterred and over which another might have some de facto or de jure control. ${ }^{44}$ In any event, this version of the deterrence rationale certainly supports the vicarious liability of parents for the torts committed by their children, of a foreman of the torts of her subordinates $^{45}$ or of an employer for the torts of judgment-proof independent contractors ${ }^{46}$ - positions which are clearly not the law. ${ }^{47}$ Fifth and finally, there seems something arbitrary in limiting the choice of "person-used-as-deterrence" to that of employer and the method of deterrence to the payment of compensatory damages. ${ }^{48}$ One could argue that potential tortfeasors might be better deterred if vicarious liability was imposed on a loved relation, such as a parent or adult child, and if the penalty imposed was the payment of exemplary damages, the loss of their liberty or the confiscation of a favoured privileges (such as their licence to drive). Thus, much like the employer-centred version of deterrence, the employeecentred version fails to explain vicarious liability.

\section{LOSS-SPREADING}

Another leading explanation of vicarious liability is that of loss-spreading, namely that in fixing liability on the employer, the burden of the injury will be spread out among his customers and insurers. ${ }^{49}$ As Traynor J. argued in Escola v. Coca-Cola Bottling Co., "[t]he cost of an injury and the loss of time or health may be an overwhelming misfortune to the person injured, and a needless one, for the risk on injury can be insured by the [employer] and distributed among the public as a cost of doing business." 50 Much like the other explanations of vicarious liability, loss-spreading suffers from numerous difficulties in accounting for the doctrine of vicarious liability. First, it cannot explain why vicarious

As Aslen \& MacLeod, supra note 37 at 13 argue: "In many important situations ... agent insolvency is the rule, not the exception." See also David Goddard. "Corporate Personality - Limited Recourse and its Limits" in Ross Grantham \& Charles Rickett, eds., Corporate Personaliny in the 20th Century' (Oxford: Hart Publishing, 1998) II at 33-34; Atiyah, supra note 10 at 22.

See McBride \& Bagshaw, supra note 12 al 639 who note: "[I] [deterrence] is correct, one would expect the law to say that $A$ will be held vicariously liable in respect of B's tort if $A$ could possibly have done something to prevent that tort being committed. But it does not say this and it has never said this." As Williams argues: "in many situations it is not the master who is in the best position to prevent injury being caused by a workman, but some superior servant... If the avoidance of harm justifies [vicarious liability ] ... one would expect strict responsibility to be cast on all the superior servants" (Williams, "Master's Indemnity," supra note 33 at 439).

*. See Arlen \& MacLeod, supra note 37 who argue for the abolition of the independent contractor/employee distinction on deterrence grounds for "wealth constrained" and "judgment-proof" independent contractors.

17 See authority cited in Part $I$ of this article.

* For a similar point in relation to compensation, see Flannigan, supra note 24 at 28.

") This was the argument generally favoured by Atiyah, supra note 10 at 27 who described it as "the most rational justification that can be oflered for vicarious liability today." See also Young B. Smith, "Frolic and Detour" (1923) 23 Colum. L. Rev. 444 at 456: Williams. "Master's Indemnity." supra nole 33 in 442. For judicial suppont, sec Bazley, supra note" 23 at para. 31: "the employer is often in the best position to spread the losses [caused by an employee's tort] through mechanisms like insurance and higher prices, thus minimizing the dislocative effect of the tort within society." McLachlin J.: Lister v. Hesley Hall, supro note 6 at para. 65, Lord Millet; London Drugs, supra note 34 at 338-39, La Forest J.: Dubai Aluminium v. Salaam. [2003]2 A.C. 366, [2002] UKHL 48 at para. 107, Lord Millet [Dubai]. 
liability is imposed in situations where the loss cannot be spread." For example, it is clear that an employer of a domestic servant is vicariously liable for her employee's torts even though this cannot be spread through a customer base and regardless of insurance. ${ }^{32}$ Likewise, it is difficult to envisage, in the absence of insurance which might or might not be readily available, how a charity might distribute these losses onto the community, ${ }^{33}$ yet it is trite law that they may be held vicariously liable. ${ }^{54}$ Second, the rationale does not explain why the loss-spreading "vehicle" must be the employer as opposed to a scheme of social insurance or through vicarious liability imposed on the government. ${ }^{\text {s" }}$ Third, the rationale could be used to impose vicarious liability for the torts of independent contractors if it turned out empirically that the employer could better spread the loss than a particular contractor or class of contractor. ${ }^{56}$ And fourth, the loss-spreading justification does not explain why the loss to be dissipated must be both a tort and committed in the course of employment, as opposed to a naturally caused catastrophic illness or an accidental self-inflicted injury. ${ }^{57}$ Therefore, because of its inability to account for the central features of the doctrine, loss-spreading is not an adequate explanation of vicarious liability.

\section{E. ENTERPRISE LIABILITY}

Another prominent explanation for vicarious liability is that of enterprise liability. Although there are a multitude of different versions of these theories, they generally come in one of two broad forms. The first, as typified in the writings of Gregory Keating ${ }^{58}$ and Jane

See e.g. the criticism of Callinan J. in V'abu, supra nole 5 at paras. 115-17 that the assumptions underlying loss-spreading (such as the ability 10 raise prices or obtain insurance) are merely assumptions and not fact.

It was also submitted by the appellant that the imposition of liability upon the respondent would provide an efficient means of passing on losses to insurers ... [since] the "respondent's enterprise" ... [is] a legal personality better able to assess the risks. and pay the insurance necessary to cover them. This last submission reflects assumptions about the equitable distribution of losses and economic efficiencies often made by authors of textbooks, and, on occasion, judges... There are ... difficulties about these sorts of assumptions. They are only assumptions. They may, 1 suspect. have been made without access to all of the relevant information, and not always after rigorous scrutiny by people adequately qualified to process and evaluale that information. a similar point, see Williams, "Master's Indemnity," supra note 33 at 441.

Sec McBride \& Bagshaw, supra note 12 at 639, n. 33. See also Klar, "Judicial Activism," supra note 24 at 238, n. 83 and judgment of the majority in Jacobi v. Griffiths, [1999] 2 S.C.R. 570. Binnie J. [Jacobi] which doubt the applicability of the loss-spreading rationale to charities.

See e.g., Mersey Docks and Harbour Board v. Proctor, [1861-73] All E.R. Rep. 397 (H.L.): Jolm Doe v. Bennett, [2004] I S.C.R. 436; and the discussion in David R. Wingfield, "The Short Life and Long After Life of Charitable Immunity in the Common Law" (2003) 82 Can. Bar Rev. 315 Weinrib. Private Law', supra note 18 at 37: Flannigan. supra note 24 at 29.

s. Flannigan, lbid.

s7 Jane Stapleton. Product Liability (London: Butlerworths. 1994) at 193: Weinrib, Private Lait, supra note 18 at 185, n. 27: Atiyah, supra note 10 at 27-28; McBride \& Bagshaw, supra note 12 at 640; F.D. Rose, "Liability for an Employee's Assaults" (1977) 40 Mod. L. Rev. 420. 
Stapleton,,$^{99}$ is based on the notion of reciprocity between benefit and burden. ${ }^{00}$ As Friendly J. noted on behalf of the Second Circuit in Ira S. Bushey \& Sons, Inc. v. United States: "respondeat superior ... rests not so much on policy grounds ... as in a deeply rooted sentiment that a business enterprise cannot justly disclaim responsibility for accidents which may fairly be said to be characteristic of its activities." ${ }^{.61}$ The second version, as typified by the Supreme Court of Canada's decision in Bazley, is that it is fair to make the employer pay because the employer's enterprise created or exacerbated the risk that the plaintiff would suffer the injury that she did..$^{\text {2 }}$

The reciprocity version of enterprise liability fails to account for many of the important aspects of vicarious liability. First, it cannot explain why charities should be vicariously liable for their employees' torts since altruistic institutions do not receive the material benefits required to render the reciprocity argument applicable against them. ${ }^{63}$ Yet it is trite law that they may be vicariously liable. ${ }^{64}$ Second, reciprocity cannot explain why the employer's vicarious liability is unlimited in amount rather than being limited to profit or assets of the enterprise (whether actual or potential)." Third, the rationale cannot explain why the enterprise is only liable for the torts committed by its employees and not all accidents caused in the search of profit. ${ }^{\circ 6}$ As Glanville Williams argued:

In an action against the master for the negligence of the servamt, it is necessary to prove the servant's negligence. This should not be the case if the underlying reason of the law is to impose upon an undertaking

") Stapleton. supra note 57 at 186: "if, in secking to securc financial profit, an enterprise causes certain types of loss, it should be legally ohliged to pay compensation to the victim."

.. For carly judicial endorsement. sec Mall v. Smihh (1824). 2 Bi I56. Best C.J. and Duncan v. Findlater. [1839] VI Cl \& Fin 894, 7 LE.R. 934, Lord Brougham. l'or more modern authority, see Dubat, supra note 49 at para. 21. Lord Nicholls: "The ... legal policy [underlying the law on vicarious liability] is based on the recognition that cartying on a business enlerprise necessarily involves risks to others. It involves the risk that others will be harmed by wrongful acts committed by the [employees] through whom the business is carried on. When those risks ripen into loss, it is just that the business should be responsible for compensating the person who has been wronged." $398 \mathrm{li} .2 \mathrm{~d} 167$ at 171 (2d Cir. 1968).

6. As was argued by McLachlin J. for the court: "The employer puls in the community an enterprise which carries with it certain risks. When those risks materialize and cause injury to a member of the public despite the employer's reasonable eflorts, it is fair that the person or organization that creates the enterprise and hence the risk should bear the loss. This accords with the notion that it is right and just that the person who creales a risk bear the loss when the risk ripens into harm." Ba=ley. supra note 23 at para. 31. See also Lister y. Hesley' Hall, supra note 6 at para 65. Lord Millet. For an cconomic justification of enterprise risk, see Simon Deakin. 'Enterprise-Risk': The Juridical Nature of the Firm Revisited" (2003) 32 Industrial 1.J. 97.

(1) See Riggs, supra note 26 at 101 where he argues that such theories sit "awkwardly in the case of organizations like churches or Girl Guides which are arguably created to provide benefits - not to receive them." See also Klar, Tort Law, supra note 4 at 581: McBride \& Bagshaw, supra note 12 at 640, n. 33; Williams, "Master's Indemnity." supra note 33 at 230: Schwartz. supra note 4 at 1750. n. 61.

in See aulhority cited supra nole 54 .

1. Sec Baty, supra note 3 at 147. For example in the Roman law and medieval civil law there was, in many commercial circumstances. "an equivalence between the value of the property [engaged in the entesprise) and the owner s liability arising from it" (David Jolınston, "I.imiting L.iability: Roman L.aw and the Civil Law Tradition" (1995) 70 Chicago-Kent L. Rev. 1515 at 1536; see also R. Zimmerman. The Law of Obligations: Roman Foundations of the Civitian Tradision (Oxford: Oxford University Press, 1996) at (118).

". Alan O. Sykes "An Efficiency Analysis of Vicarious Liability under the l.aw of Agency" (1981) 91 Yale L.J. 168 at 173 
the social loss caused by its operations. A loss caused without negligence is just as much a loss as one caused by negligence. For example, neither a Irading firm nor its vanmen can avoid some traffic accidents: yet these accidents are part of the social cost of the tirm's activities. ${ }^{67}$

Fourth, the theory has difficulty explaining the lack of vicarious liability for independent contractors since that is a situation of mutual profit, mutual benefit and burden. ${ }^{68}$ Now as Stapleton and Atiyah suggest, this rule can be saved if one accepts that "the benefit derived from an independent contractor's services is fixed and predetermined, [and] the benefit from the services of employees is open-ended" further clarification is introduced, it would not explain why beneficiaries or shareholders are not vicariously liable for the torts of their trustees or directors since they too are equity stakeholders." A fitth, related objection, is that the reciprocity rationale cannot explain why vicarious liability is limited to the employee/employer relationship, since if the rationale was taken seriously the common law would have a scheme of strict liability for business torts ${ }^{\text {?2 }}$ - which is certainly not the law. ${ }^{73}$ Sixth and finally, the reciprocity rationale has difficulty explaining why the employee remains personally liable for his or her tort after that fort has been ascribed to the employer's enterprise, since the rationale supposes that it is the enterprise which benefits and therefore it is the enterprise which should bear the burden. ${ }^{74}$

Unfortunately, the enterprise risk version of the rationale is not any more successful in explaining the current limits of vicarious liability except to the extent that it would allow vicarious liability to be imposed on charities. ${ }^{75}$ Moreover, if this explanation were to expand to its logical limits, it would pose an even greater divergence with the current law than does

Williams. "Master's Indemnity." supra note 33 at 442.

1.* See Harold J. Laski, "Jhe Basis of Vicarious Liability" (19|6) 26 Yale L.J. 105; McBride \& Bagslıaw. supra note 12 at 639-40; Stapleton, supra note 57 at 190. As Baty, supra note 3 at 32 arguts. if reciprocity were taken literally everyone who hires a taxi cab would be placed "in an unenviable situation!" Likewise, as Williams argued: "In a society based on the division of labour we are all constantly receiveing benefit from the work of others, but this does not, and cannot, make us legally liable for their wickedness and mistakes" (see "Master"s Indeınnity," supra note 33 at 230). See also Klar, Tori Law, supra note 4 at 586. Stapleton, supra note 57 at 190-91.

Atiyah, supra note 10 at 18.

Atiyah himself notes this fact later on the same page but does not realize its significance: "If a company makes very large profits in any one year due to the exertions of its men. the company may indeed be faced with demands for increased wages in the following yeat, but the fact remains that the surplus profit earned by the company during that year goes to llic ordinary sliareliolders." /bid.

See Schwartz, supra note 4 at $1750, n .61$.

Cane, Anatomy, supra note 29 at 46, n. 16 (The reciprocity theory "would justify the imposition of strict liability in a wide range of situations in which it is currently not imposed.") The position is of course different in many jurisdictions in the United Stales which have adopted judge-made systems of products liability, hence many of the leading American articles on the topic are not so nuch attempting to explain vicarious liability but rather attempting to show that vicarious liability fits with this growing body of products liability law, set e.g. Keating. supra note 58: Robert L. Rabin. "Some Thoughts on the Ideology of Enterprise Liability" (1996) 55 Md. I. Rev 1190. See the judgment of La Forest J. in London Drugs, stupra note 34 where he argued for the abolition of the employec's personal fiability. See also Stapleton, supra note $\$ 7$ at 193 , arguing for such a move. One suspects that the Supreme Court adopted this versium of the thenry since the defiendant in $B a=l \cdot y^{*}$ was a charity which did not receive the financial profit necessary to render it liable under the reciprocily version of the theory. While justifying the vicarious liability of charitics. the theory poses other problems such as justifying the imposition of vicarious liability on parents for their children's torts. see Markesinis, Markesinis and Deakin, supra note 12 at 572. n. 233. 
the reciprocity version, since it would countenance a general regime of strict liability for the imposition of all risk, as opposed to one limited by the profit motive. ${ }^{76}$ Therefore, much like the rationales of control, compensation, deterrence and loss-spreading, enterprise liability (in both its forms) cannot hope to explain the doctrine of vicarious liability.

\section{F. MIXEd Policy}

Given the failure of the leading justifications of vicarious liability to explain the contours of the doctrine individually, many leading jurists have argued that vicarious liability is instead explained by a combination of these policy considerations." As Bryant Smith famously remarked in 1949:

[A]ssuming that the doctrine is to be justified, is not its justification more properly to be found along the following line of thought? Masters are liable for the negligent injuries done by their servants to third persons because: 1. As a rule the master controls the conduct of the business and is usually therefore in a better position than ... anyone else except the servant ... to prevent such injuries. 2. In general, the master selects the servant and here also he has an opportunity, denied to third persons. by care and intelligence in the cltoice. to keep down the risks. 3. Ordinarily the servant is doing the master's work and the risk is therefore not improperly regarded as one of the hazards of the business. To protect the master against responsibility beyond this principle, his liability is extended only to the injuries done "in the course of the employment." 4 . The master as a rule gets the profits... 5 . In most instances, though not in all, the master is better able to pay, and it is just, as between him and the innocent third person, to put upon the master the risk of the servant's inability to pay.... 6. Usually, though not always, the master is in a better position than the third person to spread the risk onto the community as a whole. And so on through the ... reasons that might be offered. ${ }^{78}$

While there is some hope that the combination of rationales may explain the contours of vicarious liability, there are a number of reasons to doubt that this is the case. First, some of the rationales are inconsistent. As Flannigan explains: "The deep pocket justification makes the employer liable because he is able to bear the loss. The loss distribution justification, on the other hand, makes the employer liable because he is able to avoid bearing the loss." Second, even if one combines the various rationales, many of the central elements of vicarious liability are still difficult to explain. For example, Stapleton notes that none of the modern rationales, save perhaps some versions of deterrence, would justify limiting an

As Klar questions in relation to Bazley: "Would [risk creation] not be a strong rationale for the introduction of strict liability in product liability cases, for example? Is McLachlin J. (as she then was) signalling a willingness on the part of the Supreme Court to tethink Canadian tor law's commitment to negligence law and to move more aggressively towards strict liability...?" ("Judicial Activism." supra note 24 at 238). For a similar concern, see "Master's Indemnity." supro note 33 at 439 where Williams argues: "the prevention of injury is not generally regarded as the sole aim ... of the law of tort. Were it so, the argument would result in strict responsibility for harm caused by the defiendant. however remotely... [I]t would be neither a workable nor a just law." See also Rogers, Winfreld and Jolowicz. supra note 4 at 704. For a reasoned judicial rejection of generalized strict liability, see Wugener $v$. Pharmacare Lid., [2003] All S.A. 167 (S.C.A.).

See Fleming, supra note 20 at 410; Rogers, Winfielt and dolowice. ibid. at 704: Markesinis \& Unberath, supra nole 32 at 694: Stephen Waddans, Dimensions of Privale Law: Anglo-dmerican Categories and Concepts (Cambridge: Cambridge Universily Press, 2003) at 102-104. 
employer's liability solely to tortiously caused injury. ${ }^{80}$ Likewise, John G. Fleming argues that the combined rationales approach points to eliminating the personal liability of the employee and having this liability channelled through the employer alone. ${ }^{81}$ Third, the combined approach would seemingly still have difficulty limiting the doctrine of vicarious liability to its current well-accepted limits since all the rationales, save perhaps some versions of enterprise liability, point to the imposition of vicarious liability on parents for the torts of their children. As a result of these deficiencies, it seems evident that any number of vicarious liability regimes might be supported by the combined policies such that even together they do not really explain why we have these doctrinal rules and not others. Thus, although it might be possible to argue that the current doctrinal limitations of vicarious liability are the perfect instantiation of the control, compensation, deterrence, loss-spreading and enterprise liability rationales which optimally combines their logic and which perfectly balances all their contradictions and incoherences, that this were indeed so "would be a coincidence of Panglossian proportion."

\section{AN EXPLANATION OF VICARIOUS LIABILITY}

Having discounted the main rationales that have been offered to explain vicarious liability, this article will now outline a theory which comprehensively explains the doctrine. ${ }^{83}$ The mistake with most of the prevailing rationales, it is submitted, is that they have focused almost exclusively on the relationship between the employer and the tort victim and the goals that would be achieved if liability were imposed. The argument of this article is that this is the wrong relationship on which to focus. Instead the focus should be on the employeeemployer relationship. Thus, it is in the realm of contract where the mystery of vicarious liability will be solved.

It is submitted that when vicarious liability is examined from this perspective, a compelling justification for the doctrine can be found in the relationship between the employer and employee - namely in the employer's implied promise in the contract of employment to indemnify the employee for harms (including legal liability) suffered by the employee in the conduct of the employer's business. Thus, control, deep pockets, reciprocity and faimess play a role in vicarious liability but a role different from that which is usually assumed by those explaining the doctrine.

\$It Stapleton, stupra note 57 at 193. See also Fleming. supra note 20 at 410.

*) Fleming, supra note 20 at 411 . See also the decision of l.a Forest J. in London Drugs, supra nulc 34 at 339.40 :

The question in this case is whether the climination of the employec's liability would significanlly impact on the policies advanced by vicarious liability. In my view. it would impact favourably on the [reciprocity] and [loss-spreating] considerations set out above and have negligible impact on [deterrence]... In my view, not only is the elimination of the possibility of the employee bearing the loss logically compatible with the vicarious liability regime. it is practically compelled by the developing logic of that regime

: Weinrib. Private Law, stipra note 18 at 41

* Portions of this part are similar to the outlines of the theory that I have given belore cither alone or with others: see Jason W. Neyers. "Canadian Corporale Law. Veil-Piercing and The Private I alw Model Corporation" (2000) 50 U.T.L.J. 173: J.W. Neyers \& D. Stevens, "Vicarious I.iability in the Chartty Sector" [forthcoming Can. Bus. L.J.]. 
If one examines the employee-employer relationship one can see immediately why such an implied promise would make sense and is fair. If $A$ is contracting to sell her labour for B's use in his enterprise, A will ask B to take on some of the risk of her acting. A will say that this is reasonable for two reasons: first, because $B$ will get most of the benefit (since $A$ is working in return for a fixed wage); second, because $A$ will be working under the control and direction of B. In order to respond to these concerns, B will promise to indemnify A against certain of her costs incurred while acting for B's benefit. B's promise of indemnity, however, will not be unlimited but rather will be tied to harms incidental to $A$ 's employment, since it is only in the course of this employment that B is benefited.

The question then becomes for which harms will $A$ be indemnified? It seems right that legal liability for simple negligence will be covered since "[e]ven the most careful person occasionally makes a mistake." ${ }^{84}$ It would also seem right that liability for intentional torts would be covered where the tort arose out of a "situation of friction"8s created by the employer and the employee's actions could be classified as a good faith performance of the contract of employment. ${ }^{86}$ Legal liability for other intentional torts and gross negligence ${ }^{87}$ would be excluded since it can hardly seem rational that an employer would indemnify unrelated frolics and wrongs over which the employee has some real control. ${ }^{88}$

Williams, "Master's Indemnity," supra nole 33 at 444. As Lord Nicholls argued in Dubai, supra note 49 at para. 21: "liability for agents should not be striclly confined to acts done with the employer's authority. Negligence can be expected to occur from time to time. Everyone makes mistakes at times." See Bazley, supra note 23 at para. 17. See also Lister v. Hesley Hall, supra note 6 al para. 80. Lord Millet.

*. As was stated by Gummow and Hayme JJ. in their joint judgment in Lepore, supra note 5 at para. 234 "Many cases in which it is sought to hold an employer vicariously liable for the intentional ton of an employee can be determined by reference to the first of these elements. The act of which complaint is made can be seen to have been done in the intended performance of the lask which the employee was employed to perform." For a similar view, see Lister v. Hesley Hall, supra note 6 at para. 17, Lord Steyn: "It is easy to aceept the idea that where an employec acts for the benefit of his employer, or intends to do so, that is strong evidence that he was acting in the course of his employment": Dubui, supra note 49 at para. 30, Lord Nicholls. The classic cases explicable on this basis include: Dyer $v$. Munday, (1895] I Q.B. 742 (C.A.) (furniture repossessor); Poland v. Parr, [1927] 1 K.B. 236 (C.A.) (servant protecting employer's propeny from theft); Daniels $v$. Whetstone Entertainments. Lid. [ [1962] 2 Lloyd's Rep. 1 (C.A.) (dance hall bouncer): Ryan v. Fildes, [1938] 3 All E.R. 517 (K.B.) (schoolteachers" discipline); Rac: v. Home Office, [1994] 2 A.C. 45 (H.L.) (overzealous prison officers): Brown v. Robinson, [2004] UKPC 56 (overzealous security guard). The partnership case of Dubai, supra note 49 may also be explicable on this basis, see the judgment of Lord Nicholls at para. 35 where he argues that the partner in question was "secking to promote the business of the firm." Although gross negligence has been described as a term "not susceptible of definition" (Occhino $v$. Winnipeg (City) (1988), 5I D.L.R. (4th) 546 at 548 (Man. C.A.)) or nothing more than negligence with the addition of a "vituperative epithet" (Wilson v. Brett (1843), $11 \mathrm{M} \& \mathrm{~W} / 13$ at 115 ) it is submitted that a workable definition of the concept is "conduct in which ... there is a very marked departure from the standards by which responsible and competent people ... habitually govern themselves" McCulloch v. Murray: [1942] S.C.R. 141 at 145. Duff C.J.C., approved in Goulais v. Restoule Estate. [1975] I S.C.R. 365. For a slightly different definition to similar effect, see Canada v. Camada Sreamship Line.s LAd. | |1950| S.C.R. 532 at 537, Rinfret C.J.C. ("faute lourde consiste a ne pas apporet aux aflaires d'autrui le soin que les personnes les moins soigneuses et les plus stupides ne manquent pas d'apporter a leurs affaires"). In any event. questions of grosis negligence are often at issue in respect to the invocation of exclusion and indemnity clauses in other contexts, see e.g., The Hellespont Ardent. [1997] 2 Lloyd's Rep. 547 (Q.B.D.); The Happy Ranger. [2001] 2 Lloyd's Rep. 530 (Q.B.D.). 
The vicarious liability claim against the employer is then derived in the following manner. If the employee commits a tort in the course of employment, his or her victim has a right of action against the assets of the employee. If the tort was committed in the course of employment (i.e. meets the terms of the indemnity), one asset which the employee holds is her right of indemnity against the employer. The employee can then compensate the tort victim by transferring to them this valuable right ${ }^{89}$ Given that in most situations the employer will be the one who actually pays, the law eliminates a duplicity of actions by allowing the tort victim to sue the employer directly without necessarily joining the employee. ${ }^{90}$ Thus, the employer becomes vicariously liable because the tort victim is subrogated to the employee's right of indemnity.

The next test for the theory is to assess whether or not it can explain the central features and limits of the doctrine of vicarious liability. It is submitted that the indemnification model can account for these doctrinal facts. First, unlike the compensation and enterprise liability rationales, the theory can explain why in order to engage vicarious liability, the employee must have committed a tort rather than merely adversely affecting the plaintiff. This is due to the simple fact that if the employee has not committed a tort, and hence bears no liability, there is no harm for which to be indemnified.

It may seem strange to argue that one can transfer a riglt of indemnity since it is common to assume that in order to exercise such a right one first has to "pay to be paid." In general, this assumption is incorrect. As Lord Brandon explained in Firma C-Trade S.A. Y. Newcastle P \& I Assn. [1991] 2 A.C. I at 28 [The Padre /sland]:

There is no doubt that before the passing of the Supreme Court of Judicature Acts 1873 and 1875 . there was a difference between the remedies available to enforce an ordinary contract of indemnity ... at law on the one hand and in equity on the other. At law the party to be indemnified had to discharge the liability himself first and then sue the indemnifier for damages for breach of contract. In equity an ordinary contract of indemnity could be directed to be specifically performed by ordering that the indemnifier should pay the amount concerned directly to the third party to whom the liability was owed or ... to the party to be indernnified.... There is further no doubt that since the passing of the Supreme Court of Judicature Acts 1873 and 1875 the equitable remedy has prevailed over the remedy at law

See also Johnston v. Salvage Association (1887), 19 Q.B.D. 458 (C.A.); British Union and Natıonal Insurance Co. v. Rawson. [19l6] 2 Ch. 476 (C.A.). Hence an employee may transfer this right to indemnity to a ton victim and that victim, standing in the shoes of the employee, may request full payment from the employer to herself.

* David Stevens, "The Regulation of Takeovers and the ldea of the Corporation" [1994/95] Meredith Lecfures 372 at 422 : Neyers, supra note 83 at 197-98. One criticism of the indemnity theory that might be made is that by allowing a suit directly against the tmployer it affords a bankruptcy priority to the tort viclim over other creditors of an insolvent cmployec. Moreover, the argument runs, this is counter to the English Coun of Appeal's controversial decision in In Re Harrington Motor Company. Lrd. [1928] Ch. 105 (C.A.) [Re Harrington], which held that the duty of the trustee in bankruptcy is to call upon the indemnifier to pay the amount concerned directly to the bankrupt so that these funds might be shared pro rata amongst her creditors. A full answer to this criticism is beyond the scope of this article but a partial answer can be made along the following lines. First. the criticism does not apply to situations where the right to indemnity has been explicitly or implicitly transferred before bunkrupicy sinee the right would then be in the hands of the employec (see $e$.g. the discussion of Lawrence $L . J$. in Re Harrington at 124-25). Second, even post-bankruptcy, it is not at all clear whether the holding in Re Harrington survives their Lordships decision in Lord Napier and Eurrick v. Hunter. [1993] A.C. 713, which provides a proprietary claim to those who are entitled to subrogation. In any event, it must be admitted that ifCommonwealth cours adopted the indemnification model of vicarious liability, they and their relevant legislators would have to squarely face the issue of bankruplcy priority in light of existing insolvency regimes. 
Second, the theory explains why the tortfeasor must be an employee - since if the tortfeasor is not an employee he or she will not have a right of indemnity from the person sought to be made vicariously liable. This logic also explains why vicarious liability is not imposed in the various other relationships noted in Part I. A parent is not vicariously liable for the torts of her children qua parent since their presumed lack of intention to enter legal relations negates the possibility of a contract of indemnity." A superior servant is not vicariously liable for a subordinate since the subordinate has a right of indemnity against their joint employer, not the superior. Likewise, beneficiaries are not generally vicariously liable for the torts of their trustees since the trustees have a right of indemnity for the trust corpus rather than from any beneficiary. ${ }^{22}$ Similarly, shareholders are not vicariously liable for company employees and directors who have their right of indemnity from the corporate patrimony. ${ }^{93}$ Finally, employers are not vicariously liable for the torts committed by independent contractors since these actors are trading on their own account and for their own financial benefit and hence are not offered any indemnification. ${ }^{94}$ In fact, an independent contractor has to indemnify her employer should a failing on her part render that employer tortiously liable."s

Third, the indemnification model of vicarious liability can also explain why an employer is only liable for torts committed by her employee in the course of her employment. As mentioned above, this is due to the fact that it is only when the employee is acting on behalf of the employer that the employer will have a chance of reaping profit, hence the indemnification, and the vicarious liability which is a consequence thereof, is limited to just those circumstances.

Fourth, this theory of vicarious liability explains why the employee and employer are treated as joint tortfeasors both amenable to suit by the tort victim. The answer is simple: the employer can be sued because the tort victim is subrogated to the contractual indemnity, the employee because she committed a civil wrong.

Fifth and finally, unlike the enterprise liability, loss-spreading or compensation rationales, the theory also explains how the doctrine of vicarious liability can co-exist coherently with the more pervasive regime of fault. The model of vicarious liability herein proposed does not cause any difficulties given that, under it, an employer is not liable because of some quasifault or gain-based principle of strict liability, i.e. a tort analysis, but rather because she has assumed responsibility under the regime of contract.

\section{POSSIBLE OBJECTIONS TO THE: TIE.ORY}

While the indemnity theory explains the central features and doctrinal limits of vicarious liability, several possible objections could be made to it. The four most powerful of these

Balfour v. Balfour, [1919] 2 K.B. 57 (C.A.); Jone.s v. Padavafion, [1969] 2 All E.R. 616 (C.A.). As mentioned above, supra note 15, parents will be vicariously liable where the presumption has been rebutted and their children have become their employees.

12. See authority cited supra note 17.

3) See Neyers, supra note 83 at 197-99.

* For cases defining the distinction between employees and independent contractors in these terms, sec authority cited in Part IV, infra.

" See Honeywill \& Stein Lid. v. L.arkin Brothers Lrd. [1934] I K. B. 191 (C.A.) [Honeywill \& Stein] 
objections are as follows. First, the theory is flatly contradicted by high case authority, namely the House of Lords decision in Lister v. Romford lce \& Cold Storage Co. ${ }^{96}$ Second, the contractual model of vicarious liability cannot explain how vicarious liability could be a rule of law since if the theory were true every employer would henceforth explicitly exclude the right to indemnity in every contract of employment. Third, the theory cannot account for the leading cases, both classic and modern, that have posited liability for those intentional torts which could in no way be seen as good faith efforts to perform the contract of employment. Cases in this category include: Lloyd v. Grace, Smith \& Co.," Morris v. C.W. Martin \& Sons Lid. ${ }^{98}$ Bazley v. Curry and Lister v. Hesley Hall Lid. ${ }^{100}$ And fourth, the theory is under-inclusive since it cannot explain why vicarious liability is imposed in noncontractual situations such as those found in the "casual delegation" situations exemplified by cases such as Ormrod v. Crosville Motor Services Lrd. ${ }^{101}$ These possible objections will now be taken up in turn.

\section{A. CONFLICT WITI LISTER V. ROMFORD}

As mentioned above, the primary difficulty with accepting the indemnification model of vicarious liability is that it is in conflict with the House of Lords decision in Lister $v$. Romford lce \& Cold Storage Co. ${ }^{102}$ The facts of Lister $v$. Romford are as follows. The defendant was employed by the plaintiff company. While backing up his truck in a customer's yard, the defendant negligently knocked over his father who was also employed by the company. The father then proceeded to recover damages against the company for his son's negligence. The company, at the behest of its insurers, then brought an action against the defendant son claiming that the son had to indemnify the company/insurers on the basis that the son had breached an implied term in his contract of service that he would use reasonable skill and care in driving. The son countered on two fronts: (1) that it was an implied term of his employment contract that the company would indemnify him against all claims or proceedings brought against him for any act done in the course of his employment: or, alternatively (2) that it was an implied term that he would receive the benefit of any contract of insurance effected by his employer. By a bare majority, ${ }^{103}$ their Lordships held for the employer and established that at common law, a faultless employer held vicariously liable for his employee's tort could in fact sue that employee for indemnity.

If Lister v. Romford in fact correctly stated the law, then it would be impossible for the indemnity theory of vicarious liability to adequately explain the law. There is, however, every

*. [1957] A.C. 555 (H.L.) [Lister v. Romford].

I7) [1912] A.C. 716 (H.L.) [Lloyd].

[1966] I Q.B. 716 (C.A.) [1/orris].

S) Supra note 23.

(iv) Supra note 6.

[im [1953] I W.L.R. 1120 (C.A.) [Ormrod]. See also Carberry v. Davies. [1968] 2 All E.R. 817 (C.A.).

10: The theory is also, of courst, in conflict with cases which substantially rely upon Lis/er $v$. Romford. such as Reid y. Rrush \& Tompkins Group plc. [1990] I W.L.R. 212 (C.A.), It is submilled that the reasons which impeach Lister v. Ronford also impeach Reid v. Rush \& Tompkins.

Viscount Simonds, Lord Morton of Henryton and Lord Tucker lormed the majority: L.ord Radeliffe and Lord Somervell of Harrow dissented. Lister $v$. Ronford is "one of those cases in which one feels that a slight clsange in the composition of the Appellate Committe would have sel the law on a different course." White v. Chief Constable of South Yorkshire Police, [1999] 2 A.C. 455 (H.L.) at 501, Lord Hoffmann discussing Mcloughlin v. O'Brian, [1983] I A.C. 410 (H.I.). 
reason to believe that the doctrine formulated in Lister v. Romford is incorrect. ${ }^{104}$ Evidence that this might be the case can be found in many sources. First, the decision is generally criticized in the academic literature. ${ }^{105}$ Second, numerous common law jurisdictions have either statutorily overturned the doctrine ${ }^{106}$ or sought to ameliorate its hardships through "gentleman's agreements" between employer's and insurers ensuring that it will not be enforced. ${ }^{107}$ Third, when squarely faced with arguments as to the validity of Lister $v$. Romford, various Commonwealth courts have sought to limit its scope ${ }^{108}$ or argue for its abolition. ${ }^{109}$ Fourth, most civil law jurisdictions do not have a similar rule (though they share with the common law a doctrine of vicarious liability). ${ }^{110}$ When all this is taken into account, there is a strong case to be made that Lister $v$. Romford is wrongly decided on the issue of indemnity. This consensus was probably best summarized by Williams, who argued:

I say the doctrine sinec the decision itself may be correctly decided on the basis that the employee's actions were so grossly negligent as to be beyond the "scope of employment."

IIIS See e.g., Atiyah, supra note 10 at 426 : "It is obvious that the whole foundation of vicarious liability as it operates today would be seriously affected if employers made a regular practice of suing their servants for indemnities": Markesinis, Markesinis and Deakin, supra note 12 at 597 ("one must hope that the House of Lords will ... remedy this defect. De lege ferenda, therefore, it would be best to limit such a right to an indemnity to cases where the employee intentionally in (licted loss on the victim"); Rogers, Winfield and Jolowicz, supra note 4 at 725 ("the ... principle is unjustifiable in modern conditions"); Fleming, supra note 20 at 299; Trindade \& Cane, supru note 12 at 744; Klar, Tort Law, supra note 4 at 581-82, n. 206; Geofl England, Individual Employment Law (Totonto: Inwin Law, 2000) at 52. For a positive view of the case, see J.A. Jolowicz, "The Right to Indemuity between Master and Servant" (1956) Cambridge L.J. 101 [Jolowicz. "Master and Servant"]

1*. This has occurred in several Australia states: for a listing and discussion, sec Fileming, supra note 20 at 298 and Queensland Law Reform Commission, Vicarious Liabilits, Report No. 56 (December 2001). This is still the situation in the Uniled Kingdom. For a description of the agreement, see the decision of Lord Denning M.R. in Morris v. Ford Motor Co., [1973] I Q.B. 792 (C.A.) at 798.99 [Ford]: Atiyah, supra note 10 at 426-27. For criticism of this type of regulation. see Richard Lewis, "Insurers" Agreements not to enforce Strict Legal Rights: Bargaining with Government and in the Shadow of the Law" (1985) 48 Mod. L. Rev. 275: Gerald Gardiner, "Reports of Committees" (1959) 22 Mod. L. Rev. 653.

Iox See e.g., Ford, ibid., where the English Court of Appeal refused to allow a non-insurance company to be subrogated to an employer's indemnity. As Lord Denning M.R. argued at 801 :

Lister v. Romford ... was an unfortunate decision. Its ill effects have been avoided only by an agreement between insurers not to enforce it. It should not be extended to this case. I would apply this simple principle: where the risk of a servant's negligence is covered by insuranee, his employer should not seck to make that servant liable for it. Al any rate, the courts should not compel him to allow his name to be used to do it.

As Jones, supra note 12 at 440 notes: "[T] he decision [in ford] is dit]icult to reconcile with Lister [v. Romford]." Or Kalaman v. Singer l'alve Co., [1998] 2 W.W.R. 122 (B.C.C.A.) at para. 101. Southin J.A.: "[l]t has been held that an employee is under a duty to his employer not to be careless in the performance of his work ... although whether a breach of that duty gives rise to an action in the employer for damages. in contradistinction to being grounds for dismissal, is. I think, still an open question." See also, D.H. Overmyer Co. of Canada v. Wollace Transfer Lid. (1975), 65 D.L.R. (3d) 717 (B.C.C.A.). Seaton J.A. dissenting (limiting the rule to situations of purformance of a skilled job, an or profession); Harvey v. R. G. O'Dell L.td.. [1958] 2 Q.B. 78 (not applying the rule where a person employed as store keeper caused an accident through driving since he was not generally employed to drive).

II") Sec e.g. London Drugs, supra note 34 at 334-58. La liorest J. (arguing for the indemnity regime advocated herein); Rowell v. Alexander Mackie College Of Advanced Educution (1988), 7 M. V.R. 157 (N.S.W.C.A.) at 161, Samucls J.A. ("there is no ground for regarding that case as determinative of industrial conditions at the other end of the world 30 years after it was decided"); Everist v. McEvedy. [1996] 3 N.Z.L.R 348 (H.C.) (arguing that the custom in New Zealand is that legal employers would indemnify their employee-solicitors for torts committed in the scope of their employment). 
On the whole it is submitted that it would be fair and right, and in accordance with the modern rationale of vicarious liability, that a statute should be passed to disallow an action by the master for indemnity against the servant, where the servant has been guilty only of inadventent negligence. It may be expected that many persons would approve this proposal, while jibbing at the logical corollan - that the servant who is sued shuuld be given right of indemnity against the master. 11

While, on these terms, a powerful case can be made that Lister $v$. Romford is incorrect, a traditional jurist might respond that the criticisms are misplaced since they all largely impugn the decision on the basis of policy. For example, one would assume that the various instances of legislation and the gentleman's agreement were influenced by various policy considerations such as encouraging good industrial relations or national industrial efficiency. ${ }^{12}$ Likewise, most academic commentary criticizes Lister $v$. Romford since it frustrates the rationales of vicarious liability discussed in Part II of this article, especially those of loss-spreading and enterprise risk. ${ }^{1 / 3}$ Yet, if that part of the article is correct and the rationales are not convincing explanations of the doctrine, then these criticisms of Lister $v$. Romford lose much, if not all, of their force. Thus, this traditional jurist might argue that you cannot refute a common law principle by reference to policies that are inimical and irrelevant to the judicial decision-making process. ${ }^{14}$ Yet even if one accepts the formalist position, a strong case can be made that even on its own terms - those of contract and employment law - the decision in Lister $v$. Romford is incorrect. ${ }^{.15}$

The majority in Lister $v$. Romford based its decision on the simple application of traditional contract law to the facts of the case. As Viscount Simmonds asserted:

the [piaintiff] was under a contractual obligation of care in the performance of his duty, that he commilted a breach of it, that the [company] thereby suffered damage and they are entilled to recover that damage from him. unless it is shown either that the damage is too remote or that there is some other intervening factor which precludes the recovery. ${ }^{116}$

The only intervening factor which could possibly disrupt the application of these principles, it was thought, was the implication of an indemnity term like that proposed in Part III of this article. The majority of their Lordships felt unable to imply such a term since: (1) it would cover all criminality; ${ }^{117}$ (2) no employer would agree to such a term especially if it covered

III Williams, "Master's Indemnity," stupra note 33 at 446. For a similar view: sec Goddard, supra note 43.

11: See Queensland Law Reform Conmission, supra note 106 at 91: Markesinis, Markesinis and Deakin, supra nole 12 at 596.

11, Sec e.g., Queensland Law Reform Commission, ibid. and authority ciled. supra note 105.

i1) This is the thrust of Weinrib, Private Law, supra note 18 . As llegel noted: "The genuine refutation must penetrate the opponent's stronghold and meet him on his own ground: no advantage is gained by attacking him somewhere else and defeating him where he is not." Sce II.D. L.ewis, ed.. Hegel's Science of Logic. trans. by A.V. Miller (1812-1816: London: Allen and Unwin. 1969) at 581.

is II should be made elear that even formalists except that decisions may be wrongly decided. As Weinrib notes: "The law itself announces the possibility of its own erroncous resolution of particular controversies through dissents and overrulings. Moreover, the very presence in the common law of reasons for judgment is an invitation to take those reasons seritusly as reasons. and therefore to entertain the possibility that they may be right or wrong. sound or unsound. adequate or inadequate." Weinrib, Private Law, supra note 18 at 13.

11. Lister v. Romford, supra note 96 at 573.

11 Ibid. at 574. Viscount Simonds. 
gross negligence ${ }^{118}$ and was not limited to matters which the employer insured themselves; ${ }^{119}$ (3) it would not encourage employees to be careful; ${ }^{120}(4)$ it would be in conflict with the well-accepted implied term of care and skill;; ${ }^{121}$ and (5) it was too vague and not required to give business efficacy to this particular contract of employment. ${ }^{122}$

In responding to the arguments of the majority, it must be remembered that their Lordships were disadvantaged in that they decided Lister $v$. Romford without the benefit of two lines of modern case law which bear on this issue: one dealing with the special nature of the contract of employment and the other dealing with the distinction between an employee and an independent contractor. The relevance of the latter line of cases will be discussed below, but the former was clearly relevant to the basic underpinning of the reasons - namely, that Lister $v$. Romford was to be decided using universal contractual principles. Leading cases of more recent vintage, however, such as Mahmud v. Bank of Credit and Commerce International $S A^{123}$ and Wallace v. United Grain Growers Lid., ${ }^{124}$ suggest that the employment contract, because of its fundamental importance to our lives, is one that has special doctrinal rules - the most important of which is that the "employer must treat his employees fairly." 225 With the uniqueness of the contract of employment in mind, one can now assess the cogency of the arguments raised by the majority.

Their Lordships' concern that an indemnity would cover all criminality is misplaced since the indemnity herein proposed applies to harms suffered in the course of employment, and therefore, criminal conduct, except in the very limited circumstances noted above, ${ }^{126}$ is not to be indemnified. The limitation as to course of employment also deals with the wariness that some of their Lordships had with covering gross negligence, since gross negligence is not to be indemnified either.

In regard to the concerns expressed that no employer would agree to such an indemnity and that therefore it was not necessary for business efficacy, it is submitted that it does in fact

lbid. at 578. As Viscount Simonds argued:

Is it certain that, if the imaginary driver had said to his employer: "Of course you will indemnify me against any damage that I may do however gross my negligence may be," the employer would have said: "Yes, of course!"? For myselfl cannot answer confidently that he would have said so or ought to have said so. It may well be that if such a discussion had taken place it might have ended in some agreement between them or in the driver not entering the service of that employer. That I do not know. But I do know that I am ever driven further from an assured certainty what is the term which the law imports into the contract of service between the employer and the driver of a motor-vehicle.

Ibid. at 595. As Lord Tucker argued:

Is it to be confined to the relationship of master and servant with reference to motor-cass, or is it to extend to all those employed in industry or transport who, in the very nature of things, are engaged on work in which negligence on their part may result in widespread and grievous damage amounting to thousands of pounds for whiclt they may be liable to their employers and in respect of risks which it was customary for the employer to insure against long before the advent of the motor-ear?

Ibid. at 579, Viscoum Simonds.

lbid. at 584, Lord Morton and at 593, Lord Tucker.

lbid. at 583, Lord Monton.

[1998] A.C. 20 (H.L.).

[1997] 3 S.C.R. 701.

Eastwood v. Magnox Electric plc, [2004] UKHL, 35 at para. 11 (BAILII), Lord Nicholls of Birkenhead.

See text surrounding note 86 , stipra. 
make sense for employers to agree to indemnify: both to encourage good industrial relations $^{127}$ and to obviate the need for double insurance with its concomitant wage pressures. ${ }^{128}$ In any event, if faimess is important in construing the employment contract, as modern authority suggests, indemnification is clearly the fairer term. ${ }^{129}$ As Lord Somervell of Harrow noted, cogently bringing these arguments together:

When a man is engaged as a chauffeur or a lorry driver the question whether his resources are at risk should he cause damage through his negligence is as important to him as it is to an owner driver. Nothing was said in this case and I dare say nothing is usually said. If, when such a contract was being negoliated, the question had been raised, it is obvious, I think, that the driver would have stipulated for the usual cover that an owner driver provides for himself. If nothing is said it is, in my opinion. for the employer to see that the driver's resources are protected by insurance. It is inconsistent with such an obligation that the employer should seck by action to make the driver personally liable as in the present case.

1 instanced during the argument the case of an owner who drives himself at times and at other times employs a chaulfeur. "Unreasonable" would be too mild an epithel if the owner had prolected his own resourees if he was negligent but had failed to ensure the protection of his driver or, of course, made it clear to him that he must insure himself. If the present claim succeeds that would be the posilion.

I find it easier to imply this term than the obligation of the driver to take care. This lerm stems 10 me 10 be necessary for the efficacy of the contract. No driver would undertake the work if he was told his resources might be liable for damage caused by a negligent act or omission.

See e.g., the comments of Denning L.J. at the Court of Appeal [1956] 2 Q.B. 180 at 192 [Lister v. Romford(C.A.)]: "II] this action is well founded, it means that in every ont of these cases the insurance company can turn round and bring an action in the name of the employer against the servant. Nothing could be more detrimental to good relations between an employer and his servants. Nothing could be further from the contemplation of the parties."

12. As Jolowicz noted in his comment on Lister $v$. Romford, the effect of the decision would be to encourage both the employec and the employer to take out insurance; see Jolowicz., "Master and Servant," supra note 105 at 111 . See the similar comments of 1 .ord Radelifle, I.ister $v$. Romford, supra note 96 at 588 :

Now, the insurance policy required could nol come inlo existence of ils own motion. One of the two parties, employer and employed, had to assume responsibility for laking it out or keeping it running and for paying up the necessary premiums to buy the cover. To which of them ought we to attribute that responsibility, having regard to the relationship of the parties? In my view, to the employer. I cannot suppose that, short of special stipulation. any other answer would be given in such a case.

12. See also the comments of Denning L.J. in Lisfer v. Romford (C.A.). supra note 127 at 186:

[T]here was until very recently never a case of this kind recorded in our hooks. Many a naster has been made responsible for the mistakes of his servants, but never las lie souglit to get contribution or indemnity from his servants... The master is not allowed to make any deduction from his servant's wages: and it would seem the extreme ol harshness to seize his savings or to make him bankrupt. The other reason is no doubt the reluctance of a good master to visit the risk of accidents on to his servants. The risk slowuld be borne by the undertaking as a whole rather than by the servant who happens to make a mistake. especially when he is working his master's machine. The master takes the prolits from using the machine and should bear the responsibility for the damage it does, even though the damage would not happen without some human error. 
It is suggested that such a term would not be precise. It would, I think. be as precise as the "i" or the "f" in a c.i.f. contract. ${ }^{130}$

Moreover, whatever the position in 1957, one could argue that the repeated non-exercise by the employer or its insurers of their "indemnification rights has been so consistent over time as to render the waiver of indemnification an implied condition" of the contract of employment. $^{131}$

In regard to the arguments that to imply an indemnification term into the employment contract would be in conflict with the implied care and skill term and would encourage employees to be careless, several arguments can be made. First, there is no real conflict with the term since an employee who fails to exercise care and skill still faces the prospect of dismissal from her employment. Second, the fact that dismissal remains an option and that there is no indemnity for gross negligence still encourages employees to act safely. ${ }^{132}$ Moreover, as Lord Somervell noted, an employee has "a further sanction in that accidents causing damage are likely to hinder his advancement." 13 Third, as has been noted by others, ${ }^{134}$ an indemnity given by the employer would have no less a dampening effect on deterrence than would an indemnity given by an insurer. Thus, it is submitted that the concerns raised in Lister $v$. Romford do not stand in the way of implying the indemnity herein proposed.

A further problem with the doctrine formulated in Lister $v$. Romford is brought home when one examines the case from the perspective of the employee/independent contractor distinction. If the modern cases, such as 67//22 Ontario Ltd. v. Sagaz Industries Canada Inc. ${ }^{135}$ and Lee Ting Sang v. Chung Chi-Keung, ${ }^{136}$ are correct, ${ }^{137}$ then the heart of this distinction is that an independent contractor is an entrepreneur who takes the risk of profit and loss, whereas a employee largely foregoes both possibilities in return for a fixed salary. ${ }^{138}$ The unanticipated effect of the decision in Lister $v$. Romford, however, is to partially collapse this central distinction so that an employee becomes one who foregoes the possibility of a

Lister v. Romford, supra nole 96 at 598-99. See also the comments of Denning L.J. in Listerv. Romford (C.A.), supra note 127 at 192: "In my opinion, no such action lies. If and in so fas as the claim rests in contract. which I dispule, it is defeated by the implied term which I have just mentioned. The implied term which exempts the servant is just as plausible as the implied term which makes him liable." See also Atiyah, supra note 10 at 425 . who notes that the "minority view really carrics more conviction."

ii' Schwartz, supra note 4 at 1753.

112 For a similar view, see the judgment of La Forest J. in London Drugs, supra note 34 at 341 : "As for deterrence, imposing tort liability on the employec in these circumstances cannot be justified by the need to deter careless behaviour. An employee subjects himself to discipline or dismissal by a refusal to perform work as instructed by the cmployer. These are the real external pressures felt by an cmployee to perform well: the odds of an employee heing held personally liable remain slight." Sec also England, supra note 105 at $51-52$.

Iit Lister v. Romford, stipra note 96 at 601.

114 Rogers, Winfield and Jolowicz, supra note 4 at 726, $n$. 75, citing a privately published paper by Tony Weir.

11. Sagaz, supra note 14.

I4. [1990] 2 A.C. 374 (P.C.).

i1. As Trindade \& Cane, supra note 12 at 724 comment: "The independent business lest ... is an intuitively appealing and commonsense approach." See also England, supra note 105 at 14.

17x See also Flannigan, supra note 24 ; Market investigations, Ltd. v. Minister of Social Securin: [1968] 3 All E.R. 732 (Q.B.D.). Montreal v. Montreal locomotive Works Lid. [1947] I D.I.R. I6I (P.C.). 
gain from his work but who takes all the risk of loss associated with it. In order to overcome this collapse and to ensure the conceptual distinction between the two categories, it would seem as if the law should imply a promise of indemnity into every contract of employment as a necessary incident of that particular type of contract. ${ }^{139}$ Moreover, to do so would provide a nice parallel with the rules which apply to independent contractors since an independent contractor impliedly promises to indemnify her employer should a failing on the independent contractor's part engage that employer in legal liability. ${ }^{140}$ Thus, the nonentrepreneurial/non-risk taking employee would be one who at law has indemnity from her employer, ${ }^{141}$ while an entrepreneurial/risk-taking independent contractor would be one who at law gives an indemnity to her employer. ${ }^{142}$ To the extent that Lister $v$. Romford says otherwise, the modern cases on the employee/independent contractor distinction suggest that it was wrongly decided.

Thus, it is submitted that the doctrine formulated in Lister $v$. Romford is mistaken. The decision has been almost universally condemned in the legal literature and oft-questioned in the case law. Moreover, a strong case can be made that a promise of indemnity should be implied as a matter of fact into the contract of employment, in order to give business efficacy to, and to promote fairness within, the employer-employee relationship. Likewise, an equally strong case can be made that an indemnity should be implied as a matter of law in order to maintain the conceptual uniqueness of the contract of employment. Therefore, due to its deficiencies the House of Lords decision in Lister v. Romford does not stand in the way of the indemnification theory of vicarious liability.

\section{B. Vicarious Liability as a RULE of LAW}

Another possible objection to the theory herein proposed is that it cannot account for the fact that vicarious liability is sometimes described as a "rule of law" - a rule not subject to the parties' wills. ${ }^{143}$ This aspect of vicarious liability would apparently be difficult to justify

13. See e.g., the speech of Lord Tucker, who thought of the implied term as being implied by operation of law rather than on an "officious bystander" principle, Lister v. Romford, supra note 96 at 594 . German thinking on the matter, which is essentially correct, is that such a right to indemnity is present in every contract of employment in one form or another: see Markesinis \& Unberath, supra nole 32 at 701-702. See also the judgment of La Forest J. in London Drugs. supra note 34 at 345 where he argues: "The trends identified by the German court[s] are long-term trends common to all advanced industrial economies and 1 find these arguments very persuasive. Establishing such an indemnity regime is probably the next logical step in the development of the theory of vicarious liability. This would essentially involve bringing legal doctrine into line with the reality of modern industrial relations."

See Honeynill \& Stein, supra note 95: Fleming, supra note 20 at 300 where he argues: "Carelessness by employees is now a recognized element of the employer 's business risk: but independent contraciors are expected to absorb the losses of their business themselves by pricing of their services and insurance... It follows that, as between themselves, the contracior is primarily liable and must therefore indemnify his principal" [emphasis in original].

iv Of course, employees are not completely risk free since tluir indemnities (as well as many other of their employment based benefits) are. absent legistation. subject to the solvency of their employers

11: This conceptual distinction does away with another possible criticism of the theory herein proposed, viz. that it must be wrong since employers could be vicariously liable for independent contracturs. is result not possible in current doctrine, merely by offering such a contractor an indemnity. This argument fails as there cannot be such a thing as an "independent" contractor with an indemnity since this is a contradiction in terms. Stated difterently, a party with such an indemnity is no longer trading at their own risk and hence is in essence an employee. not an independent contractor. 
on the indemnity theory since it must follow that if the promise is found in a contract it therefore must be excludable by an agreement between the parties. ${ }^{144}$ In other words, how can the indemnification theory account for this characteristic of vicarious liability while still respecting freedom of contract?

In answering this question it must be kept in mind that the rule of law aspect of the doctrine is quite attenuated since it is currently possible for any employer to contract out of vicarious liability by simply strucfuring their relationship with the "person-chosen-to-do-thework" as one of employer-independent contractor rather than employer-employee. ${ }^{145}$ Thus, all the theory must explain is why, in an employer-employee relationship, vicarious liability might not be excludable. Phrased differently, yet more concretely, is it possible for an employer to say, both, "I employ" and "I do not promise to indemnify"?

While the common law does not often grapple with these purely conceptual and definitional problems, ${ }^{146}$ there are parallels in the doctrinal debates surrounding the irreducible core or essence of the trust, ${ }^{147}$ whether an agreement to negotiate can constitute a contract,,$^{148}$ the nature and effect of a fundamental breach of contract, ${ }^{149}$ the conceptual limitations of different types of security interests ${ }^{150}$ and the proper definition of marriage. ${ }^{(s)}$ The most salient parallel, however, has occurred in the context of liability insurance. In the classic cases, ${ }^{152}$ the issue arises in the following manner. An insurer offers the insured a

Sec e.g., the comments of Lord Diplock in Photo Production Led v. Securicor Transport Led., [1980] A.C. 827 (H.L.) at 848 [Pholo Production]: "A basic principle of the common law of contract ... is that parties to a contract are free to determine for themselves what primary obligations they will accept." As will be seen below, even Lord Diplock was prepared to accept conceptual limitations on this principle. Sec Arlen \& Macleod, supra note 37 at 28.

14. Recall $O$.W. Holmes' observation: "The life of the law has not been logic: it has been experience" $(O . W$ Holmes, The Common Law (Boston: Little. Brown, 1881) at 1) or Lord Halsbury's dicta in Quinn v. Leathem. [190]] A.C. 495 at 506, that "a case is only an authority for what it actually decides. I entirely deny that it can be quoted for a proposition that may seem to follow logically from it. Such a mode of reasoning assumes that the law is necessarily a logical code, whereas every lawyer must acknowledge that the law is not always logical at all."

14] See Armilage v. Nurse, [1998] Ch. 24 I (C.A.); David Hayton, "The Irreducible Core Content of Trustceship" in A.J. Oakley, ed. Trends in Contemporary Trust Law (Oxford: Clarendon Press, 1996) c. 3.

14k Compare Hillas and Co., Lid. v. Arcos, Lid., [1932] All B.R. Rep. 494 (H.L.) [Hillas] and Walford v. Miles, [1992] 2 A.C. 128 with Empress Towers v. Bank of Nova Scotia (1990). 73 D.L.R. (4(h) 400 (B.C.C.A.).

14" Compase Harbuut's "Plasticine" I. Id. v. Wayne Tank and Pump Co. Lid., [1970] I Q.B. 447 (C.A.) with Photo Production, supra note 144.

13" Compare Re Bank of Credit and Commerce International S.A. (No. 8), [1998] A.C. 214 (it is permissible for a debtor to take a charge over its own indebtedness, despite conceptual problems, if that is what the parties intended) with Agnew v. Commissiomer of Inland Revenue, [2001] 2 A.C. 710 (P.C.) (it is conceptually impossible to simultaneously have both a fixed charge on uncollected book debts and a lloating charge on their proceeds even if this is what the parties intended). For an interesting discussion of these cases and their relation to freedom of contact, see G. MeCormack "Lords Millett and Horfmann and the Shaping of English Commercial Law" (Paper presented to the SLS Conference in September 2004) (unpublished, copy on file with the author].

1s! See e.g. Halpern v. Canada (Attorney Generat) (2003). 65 O.R. (3d) 161 (C. A.) (declaring the common law definition of marriage, vie, the lawful union of one man and one woman to the exclusion of all others. unconstitutional).

I: Sec Woolfall \& Rimmer Lid. v. Moyle, [1942] 1 K.B. 66 (C.A.) [Woolfall]; Fraser v. B. N. Furman (Productions) Lid. [1967] I W.L.R. 898 (C.A.) [Fraser]. See also Robertsv. State Insurance, [1974] 2 N.Z.L.R. 312 (S.C.): Weston Ornumental Iron W'orks Lid v. Continental Instrance Co. [1981] O.J] 
policy that is designed to cover the insured's liability in negligence. The insurance policy contains a condition (read by the insured) which states that the insured "shall take reasonable precautions to prevent accidents."153 An accident occurs to one of the insured's workers through the negligence of the insured and the insurer refuses to indemnify on the basis of the condition. The insurer's defence is, in other words, I said both, "I insure for negligence" and "I do not promise to indemnify for negligence" and therefore freedom of contract should relieve me of liability. The courts, however, have not accepted this defence and instead have read down the condition to exclude indemnification only when the insured's conduct amounts to recklessness. The court's reasoning is succinctly explained Goddard L.J. in Woolfall \& Rimmer Lid. v. Moyle as follows:

If we were to read that condition in the way in which [the insurer] has invited us to read it, it would follow that the underwriters were saying: "We will insure you against your liability for negligence on condition that you are not negligent." because, if the plaintifl's had taken all reasonable precautions to prevent aecidents in the widest sense, they could not be liable in negligence. The fallacy which underlies [the insurer's] contention becomes apparent when it is borne in mind that we are here construing words in a contract between underwriters and assured and nol words in a contract between employer and employed. When that is appreciated it becomes reasonably clear liat [the] condition ... is introduced for the protection of the underwriters, to limit the field of their liability to the extent that they must be regarded as saying: "We will insure you against the consequences of your negligence, but please understand that we do so on the footing that you are not to regard yourselves as free to carny on your business in a reckless manner, but that you must take the reasonable precautions to prevent accidents which ordinary business people take, that is to say, you are to run your business in the ordinary way and not in a way which invites accidents." 154

As stated by the Ontario Court of Appeal, this conceptual principle of insurance law has progressed to the point where the courts will not apply an excluding condition where:

(1) it is inconsistent with the main purpose of the insurance coverage and where the result would be to vinually nullify the coverage provided by the policy; and (2) where to apply it would be contrary to the reasonable expectations of the ordinary person as to the coverage purchased. ${ }^{\text {Iss }}$

Thus, if the argument in the previous section is correct and the indemnity between the employee and employer is implied into the contract as a "necessary incident" of the contract of employment, then it would seem that it would not be excludable by the parties if their true

No. 78 (Ont. C.A.) (QL) for applications of similar principles.

Fraser, ibid. at 904.

is Woolfall. supra note 152 at 76-77. See also the judgment of Diplock L.J. in Fraser. ibid. at 905 where he states:

[The condition] means reasonable as between the insured and the insurer having regard to the commercial purpose of the contract, which is inter alia to indemnify the insured against liability for his (the insured's) personal negligence... Obviously, the condition cannot mean that the insured must take measures to avert dangers which he does not himself foresec. although the hypothetical reasonably careful employer would forsee them. That would be repugnant to the commercial purpose of the contract. for failure to toresee dangers is one of the commonest grounds of liability in negligence. What, in my view is "reasonable" as between the insured and the insurer, without being repugnant to the commercial object of the contract, is that the insured should not deliberately court a danger, the existence of which he recognises. by refraining from taking any measures to avert it. 
intent was to create an employment relationship. ${ }^{156}$ Moreover, it appears likely that any exclusionary clause inserted by the employer would most likely be read down as merely limiting the employer's indemnity obligation to situations where the employee's actions were not reckless, in bad faith or grossly negligent. ${ }^{157}$ Thus, for the foregoing reasons, the indemnification theory can account for the attenuated rule of law aspects of vicarious liability.

\section{BAD-FAITII INTENTIONAL TORTS}

Another objection that might be made against the indemnity theory of vicarious liability is that it cannot account for the leading cases where liability has been imposed for intentional torts, such as theft, fraud and sexual abuse, which are antithetical to the purpose of the contract of employment (or, as I will call them, bad-faith torts). While it is true that the theory cannot explain these cases as instances of vicarious liability, it is submitted that the results of the classic cases are straightforwardly accounted for as instances of personal fault by an employer and that the modern cases are either wrongly decided or also explicable on this basis.

The first problematic case is that of Lloyd $v$. Grace, Smith \& $C o{ }^{15 B} \operatorname{In}$ Lloyd, the plaintiff owned several pieces of property and was dissatisfied with the income derived therefrom. She therefore consulted with the defendant firm of solicitors and her affairs were handled by Sandles, the managing clerk of the firm, who conducted the conveyancing business of the firm without supervision. Through his fraud, he induced the plaintiff to convey to him her interest in the properties. He then disposed of these properties and dishonestly pocketed the proceeds. Their Lordships held that the defendant firm was liable since the deceit had occurred within the scope of Sandles' ostensible authority.

Later cases, ${ }^{199}$ and academic writing, ${ }^{160}$ have seized upon Lloyd as demonstrating that an employer can be vicariously liable for the intentional torts of her employee, even where the act complained of was a crime and was not meant to be a performance of the contract of employment. If the decision was sought to be limited so as to not make every employer vicariously liable for every bad-faith tort, this limitation was usually justified on the basis of estoppel - although fraud is usually not in the course of employment, the firm was estopped from denying this fact since the firm had held out the clerk as having the authority to

Of course, onc interpretation could be that the inconsistent promises really demonstrated that the parties intended to create an employer-independent contractor relationship but as mentioned above, this is currently permissible, and is not a challenge to the theory herein proposed. Another interpretation is that the inconsistent promises indicate that the contract is void for uncertainty. This is always a possibility but experience has demonstrated that courts are loathe to declare a contract void where it can be given meaning and where there has been substantial detrimental reliance on the contract's validity by one or both of the partics, sce /fillas, supra note 148: Foley v. Classique Coaches, LId., [1934] 2 K.B. 1 (C.A.). 
convey. ${ }^{161}$ The use of estoppel in this context has been described as "feeble," 162 no doubt since it is hard to see why clothing Sandles with authority to convey should estop the firm from asserting that he was not authorized to commit frauds. ${ }^{163}$

It is submitted that a better view of Lloyd is that it is an instance of personal liability on one of two bases. The first basis is that Sandles, as a true agent for the firm, made a contract between the firm and the plaintiff whereby the firm promised to diligently represent the plaintiffs interests. ${ }^{16-1}$ The firm then breached this contract when Sandles failed to properly deal with her account and his superiors failed to properly supervise their clerk. ${ }^{165}$ Thus, the firm was not vicariously liable for the tort of its employee but rather personally liable for its own breach of contract. ${ }^{166}$ While this adequately deals with the case, some might dismiss this reasoning as too convoluted to be convincing.

A second, more simple explanation is that Lloyd can be explained on the basis of a representation by the firm, not as to Sandles' authority, but as to his trustworthiness. It seems obvious that this is what a bank or law firm promises to potential clients in order to lure their business. ${ }^{167}$ As was argued by Dr. Baty:

The prineiple thus emerges that, alike in questions of contract and confidence, it is the individual relation between the principal and the third party, created by this invitation of confidence, which is the foundation of liability should it prove misplaced.

"You may accept his promises: you may place cash in his hands: you may rely on his statements," says in effect the principal, "and you may be assured that the promises will be performed, the cash properly applied,

Int Lepore, supra note 5 at para.108, Gaudron J. and para. 232, Gummow and Hayne JJ.: Dubai. supra note 49 at para. 28, Lord Nicholls; McBride \& Bagshaw, supra note 12 at 649-50; Max Loubser \& Elspeth Reid, "Vicarious Liability for Intentional Wrongdoing: After Lister and Dubai Aluminium in Scotland and South Africa" (2003) Juridical Rev. 143 at 150-51; Fleming, supra note 20 at 428 . Dugdale, Clerk \& Lindsell, supro note 10 at $245-46$.

16.2 Lepore, supra note 5 at para. 312, Kirby J.

in. See e.g., the comments of Baty, supra note 3 at 107-108:

At present, the seductive theory of "authority" is rampant: and masters are being declared liable for their servants' uncontemplated torts, on the ground that they have authorized them, when no such authority has ever been dreamt of, and even when it has been expressly withheld. Of course, such a doctrine can be made to work, by a lavish use of the doctrine of estoppel. But can any more ludicrously inept result be conceived? 'To create a fiction for the purpose of meeting it by another fiction is to juggle with lay figures instead of clearly facing realities.

See e.g., the speech of Earl Loreburn in Lloyd, supra not: 97 at 724 : "It was a breacli by the defendant's agent of a contract made by him as defendant's agent to apply diligence and honesty in carrying through a business within his delegated powers and entrusted to him in that capacity." See Frederick Pollock, "Judicial Records" (1913) 29 Law Q. Rev. 10. See also the comments of Denning M.R. in Morris, supra nole 98 at 727.

Irw Sec e.g., the comments or Gummow and Hayne JJ. in Lepore, supra note 5 at para. 235: "Very oflen. however, such cases will yield to simpler analysis [than vicarious liability]. The employer may be in direct breach of an obligation owed to the person who has been defrauded. That obligation may arise from a contract between the employer and the person who has been defrauded: a contract whicli can be seen as having been made by the fraudster on behalf of the employer." at 154: "Fraud often involves inducement of the victim to rely on the integrity of an institution. document or scheme." 
and the statements true." The invitation may be tacit ... but the invitation exists and he makes it, and is responsible for its consequences. ${ }^{168}$

Thus, it is submitted that $L l o y d$ can more than adequately be accounted for as an instance of personal liability.

The next of the problematic classic cases from the perspective of the indemnity theory of vicarious liability is that of Morris v. C.W. Martin \& Sons Lsd. ${ }^{169}$ In Morris, the plaintiff sent her mink stole to a local furrier to be cleaned. With the plaintiff's consent, the fur was delivered to the defendant company to be cleaned by it. While the mink was with the company, it was stolen by the employee who had been given the task of cleaning it. The fur was never recovered. The English Court of Appeal unanimously held that the company was liable to plaintiff. The true basis for this liability, however, is difficult to discern. Lord Denning M.R. clearly based his decision on the basis of non-delegable duty and personal fault of the employer. ${ }^{170}$ In contrast, Diplock L.J. clearly rested his decision on the basis of vicarious liability. ${ }^{17}$ The decision of Salmon L.J. is somewhat ambiguous though it leans ever so slightly towards a vicarious liability analysis. ${ }^{172}$

Baty, supra note 3 at 12 .

Morris, supra note 98.

Ibid. at 725. As his Lordship argued:

[I]n the ultimate analysis. (the cases] depend on the a nature of the duty owed by the master towards the person whose goods have been lost or damaged. If the master is under a duty to use due care to keep goods safely and protect them from theft and depredation, he cannot get rid of his responsibility by delegating his duty to another. If he entrusts that duty to his servant. he is answerable for the way in which the servant conducts himself therein. No matter whether the servant be negligent, fraudulent, or dishonest, the master is liable. But not when he is under no such duty. The cases show this.

He started his judgment. at ibid. at 730 , by stating "I agree that this appeal should be allowed althouglı the legal route which has led me to this conclusion is nol at all points identical with that traversed by Lord Denning. M.R." and then continued, at 736-37:

[The company] accepted the fur as bailees for reward in order to clean it. They put Morrisscy as their agent in their place to clean the fur and to take charge of it white doing so. The manner in which he conducted himself in doing that work was to conven it. What he was doing. albeil dishonestly, he was doing in the scope or course of his employment in the technical sense of that infelicitous but time-honoured phrase. The defendants as his masters are responsible for his tortious act.

It should be noted. however, that Diplock L.J. had been known to confuse vicarious liability and nondelegable duty; see e.g. his judgment in //kiw v. Samuels. [1963] I W.L.R. 99I (C.A.).

See e.g. Morris, ibid, at 739 :

It is true that Morrisscy (the employec) was in no sense the alter ego of the detendants. He was not their managing director. He was indeed one of their very junior servants. but the servant to whom they had enirusted their duty to take care of the fur and to clean it. Apart from authurily. it is in my view quite plain on principle - qui facif per alium facit per se - that the defendants are liable for what amounted to negligence and conversion by their servant in the course of his employment.

But later on, at 740-41, he comments: "A bailee for reward is not answerable for a then by any of his servants, but only for a thef by such of them as are depuled by him to discharge some part of his duty of taking reasonable care." For a similar view, see McBride \& Bagshaw. supra note 12 at $229, \mathrm{n} .41$. 
In any event, much like the decision in Lloyd, Morris has been seized on by later courts, ${ }^{173}$ and some academics, ${ }^{174}$ as further proof that an employer can be vicariously liable for the bad-faith torts committed by her employees. It is submitted, however, that since Morris can clearly be rationalized, ${ }^{175}$ and was so rationalized by one of the judges in the case, as a situation of personal fault (i.e. a breach of the non-delegable duty which the common law imposes on a sub-bailee) it does not stand in the way of recognizing an indemnity theory of vicarious liability. Moreover, as has been argued by Tony Weir ${ }^{176}$ and Nicholas J. McBride and Roderick Bagshaw, ${ }^{177}$ the fact that the same liability would have been imposed if the person stealing the fur had been an independent contractor ${ }^{178}$ means that the non-delegable duty analysis of Morris is that which is conceptually preferable. ${ }^{179}$

While the classic cases of Lloyd and Morris are readily made consistent with the indemnity theory of vicarious liability, the recent decisions of Bazley v. Curry ${ }^{180}$ and Lister $v$. Hesley Hall Ltd. ${ }^{181}$ are much more difficult to explain since they posit that an employer can

See e.g. Lister v. Hesley Hall, supra note 6: Photo Production, supra note 144 at 846, Lord Wilberforce and 852, Lord Salmon; Gilchrist Watt \& Sanderson Pry L.td v. York Products Pty Lud., [1970] I W.L.R. 1262 (P.C.), Lord Pearson; Port Swettenham Awhority v. TWWu \& Co. (M) Sdn Bhd, [1979] A.C. 580 (P.C.), Lord Salmon.

Atiyah, supra note 10 at 271 ; N.E. Palmer, Bailment, 2 d ed. (Sydney: Law Book Co., 1991) at 424-25: Rogers, Winfield and Jolowicz, supra note 4 at 722.

175 See e.g., the comments to this effect in Lepore, supra note 5 at paras. 112, 127, Gaudron J.: at 147, 161 . McHugh J. and at 236, Gummow \& Hayne JJ.; Lister v. Hesley Hall, supra note 6 at 19. Lord Steyn: Dugdale, Clerk \& Lindsell, supra note 10 at 244; Markesinis, Markesinis and Deakin, supra note 12 at 591 .

17\% Weir, supra note 12 at 102.

I7 McBride \& Bagshaw, supra note 12 at 229, n. 41.

17\% See British Road Services v. Crutchley. [1967] 2 All E.R. 792 (C.A.). See also the discussion of Trindade \& Cane, supra note 12 at 729.

17. This is due to the fact that if the thief had been an independent contractor, there could have been no vicarious liability; see McBride \& Bagshaw, supra note 12 at 229, n. 41.

Bazley, supra note 23. The facts of Bazley were as follows. The defendant was a non-profit foundation that operated residential care facilities for the treatment of emotionally troubled children. It provided. through its employees, total intervention into all aspects of the lives of the children it cared for. After performing a background check, the Foundation hired Curry to work in its home, unaware that he was a paedophile. Upon discovering that Curry had abused a clild in one of its homes, the Foundation discharged him from employment. Subsequently, the plaintiff sued the foundation to recover for the injuries he suffered at the hands of Curry. The Supreme Court unanimously lound the Foundation vicariously liable for Curry's tort since the employment. which placed him in a position of power over the plaintiff, materially increased the risk of the sexual assault. In the companion decision of Jacobt. supra note 53, the Supreme Court followed the lest set out in Basley but arrived at a different conclusion. The facts were similar. A non-profit club for boys and girls hired Griffiths to supervise its volunteer staff and to organize recreational activities and outings for the children. It was later disclosed that Griffitlss sexually abused several of the children at his home. The court held, in a four to three decision, that the club could not be vicariously liable for Griffiths' tort since there was not a close connection between Griffiths' employment and the wrong done (i.e., his employment did not inaterially increase the risk of the abuse occurring). The sisk only increased once Griftiths substantially deviated from his contract and invited the victims to his home.

Ixt Lister $v$. Hesley Hall, supra note 6. The facts of Lister 1 . Hesley /lall were as follows. The defendant company ran a boarding house for troubled children who attended a nearby school run by them. The company employed a married couple. Mr. and Mrs. Grain, to run the boarding house and maintain discipline. Unfortunalely. Mr. Grain systematically sexually abused the plaintiffs without the company's knowledge. The plaintiffs then claimed damages from the company on the basis that they were vicariously liable for the torts committed by the Grains. The House of Lords unanimously found the company vicariously liable on the basis that there was a sufficiently close connection butween the work 
be vicariously liable for an employee's bad-faith tort when there is a close connection between the employment and the tort committed. This difficulty is understandable, however, since each of the decisions suffers from serious conceptual flaws which render the conclusions reached suspect.

For example, the reasoning in the Supreme Court of Canada's decision in Bazley heavily relied on the policy rationales of deterrence, compensation and enterprise risk, which, as we have seen, cannot logically explain the doctrinal rules relating to vicarious liability. It is therefore reasonable that a theory of vicarious liability that actually attempted to explain the doctrinal rules would have difficulty explaining a decision which posits rationales that largely ignores them. ${ }^{182}$

Likewise, the House of Lords' decision in Lister v. Hesley Hall is flawed since it confuses the concept of non-delegable duty with that of vicarious liability in a way which renders portions of the judgments obtuse. ${ }^{183}$ As McBride argues forcefully:

Now - it seems that the House of Lords in Lister was completely incapable of grasping this point: that my liability in the situations [like Morris are] ... example[s] of personal liabiliny rather than vicarious liability. So - they considered: What is the position if A gives some goods to B to look after and B entrusts them to his employee, $C$, and $C$ steals the goods? Well - B will be held liable to pay A damages. Why? Because he's vicariously liable in respect of the tort committed by $C$ in stealing the goods. (Wrong: he's held personally liable because $C$ put $B$ in breach of the non-delegable duty that he owed $A$ to take reasonable steps to safeguard A's goods.) Why is he held vicariously liable? Well - because there's a "close and direct" connection between what $\mathrm{C}$ was employed to do and the tort committed by $\mathrm{C}$ in stealing the goods. Conclusion: an employer will be held vicariously liable in respect of a tor committed by an employee if there is a "close and direct" connection between what the employee was employed to do and the tort committed by the employee. Computer programmers have a term for this - "garbage in, garbage out" ("GIGO" for short). The House of Lords reached a [poor] conclusion in Lister (that an employer will be vicariously liable in respect of a tor committed by his employee if there was a "close and direct" connection between what the employee was employed to do and the tort committed by the employee) because their reasoning was based on a [poor]

that Grain had been employed to do and the acts of abuse that he had committed.

For critical commentary on Basley, see Klar, "Judicial Activism," supra note 24; Neyers \& Stevens, supra note 83; and G.H.L. Fridman, “'The Course of Employment': Policy or Principle?" (2002) 6 Newcastle L. Rev. 61 at 66 (the approach of the Supreme Court represents "the triumph of policy over principle" and may be "undesirable as well as being incorrect and unnecessary").

Lister v. Hesley Hall, supra note 6. See especially the decisions of Lord Hobhouse at paras. $54-55$ and Lord Millet at para. 82. The concepts of personal fault and vicarious liability are oflen overlapped and confused. As others have noted, the first branch of the Salmond test (wrongful acts authorized by the master) is in fact primary rather than vicarious liability: see C.A. Hopkins. "What Is The Course of Employment?" (2001) 60 C. L.J. 458 at 458 ; Lister v. Hes/ey Hall, supra note 6 at para. 65 . Lord Millet: Klar. Tort Lan', supra note 4 at 586. For another recent exampie of this confusion: see David McArdle, "His Master's Vice: Vicarious Liability for the Acts of Violent Employees after Lister v. Hesley Hall Lid." (2003) J. of Obligations \& Remedies 43 at 53 where he argues that "li]f those whose business interests extend to the night time economy fail to ensure one's potential employees are properly licensed and adequately trained; if they do not take up references or do not provide appropriatc ongoing training. the law on vicarious liability should afford then no hiding place" - i.e., that the employers should be held vicariously liable because of their personal fault. 
premise (that B's liability in the above situation is an example of vicarious liability rather than personal liability). ${ }^{184}$

This failing has also been noted by others. ${ }^{185}$ Given these conceptual deficiencies, therefore, a strong case can be made that both Bazley and Lister v. Hesley Hall are wrongly decided on the issue of vicarious liability. This was in fact the conclusion reached by the majority of the High Court of Australia in the more recent case of New South Wales v. Lepore ${ }^{186}$ which restricted vicarious liability to the classic situations of negligence and good faith torts situations of vicarious liability which are perfectly consistent with the indemnification theory of the doctrine.

With that said, however, it may be possible to reconcile the result in both Bazley and Lister v. Hesley Hall on the basis of personal fault. For example, some have suggested that the result in Lister $v$. Hesley Hall might be explained using a non-delegable duty analysis, ${ }^{187}$ an avenue which the Supreme Court of Canada has now largely foreclosed for Canadian plaintiffs. ${ }^{188}$ The trouble with this analysis is trying to determine the basis on which the nondelegable duty is to be imposed since a rational legal system can hardly conjure up such duties out of thin air. ${ }^{189}$ An additional problem with the non-delegable duty analysis on the facts of Lister $v$. Hesley Hall is discerning to whom the non-delegable duty was owed since the most likely of such duties would be the contractual duty which the boarding school owed

Nick McBride. "Lister v. Hesley Hall Lid.. The Times, May 10th 2001 HI." Case Comment, online: Pearson Education <hitp://cwx.prenhall.com/bookbind/pubbooks/ema_uk_he_mcbride_tortlaw_l/ chapterl/deluxc.html>.

Sec e.g. Weir, supra note 12 at 103 ("These distinct analyses [vicasious liability and non-delegable duty] were not kept properly apart"): Paula Giliker, "Rough Justice in an Unjust World" (2002) 65 Mod. L. Rev. 269 at 276 ("By failing to distinguish primary and vicarious liability ... the House missed a valuable opportunity to clarify the law"); Lepore, supra note 5 at para. 208, Gummow \& Hayne JJ. ("The analyses of Lord llobhouse and Lord Millell [in Lister v. Hesley Hall] have strong echoes of nondelegable duties'); Markesinis. Markesinis and Deakin. supra note 12 at 598: Deakin, supra nole 62 at 110: Mark Lunney \& Ken Oliphant, Tort Law: Text and Materials, 2d ed. (Oxford: Oxford University Press, 2003) at 789: Jones, supra note 12 at 420, 429; Brenda Barzelt. "Vicarious Liability for Acts Connected With Employment"(2000) 35 Law Teacher 391 at 397. Lepore, supra note 5, Gaudron, Gummow, Hayne \& Callinan JJ.

(n) As McBride \& Bagshaw, supra note 12, argue at 652:

[Their Lordships] could have easily found that the defiendants in Lister [v. Hesley Hall] were personally liable to compensate the claimants for the harm they suffered as a result of being sexually abused by Grain. Their Lordships could have reached this conclusion using the device of a non-delegable duty of care. They could hive ruled that: the defendants owed the claimants a non-delegable duly of care to look after them; the defendants gave Grain the job of looking after the claimants: and Grain put the defendants in breach of the non-delegable Juty of care that they owed the claimants when, by sexually abusing the claimants, he failed to look after the claimants properly. It is hard to understand why the Housc of Lords did not decide Lister [v. Hesley Hall] in this way - particularly as these were the very reasons why the llouse of Lords found that there was a "sulliciently close connection" between the torts committed by Grain in the Lister case and what he was employed to do so as to make the defendants vicariously liable in respect of those torts. owe non-delegable duty to children in fositer care): E. D. (i. v. Hammer, |2003| 2 S.C.R. 459. 2003 SCC 52 (school board does not owe non-delegable duty to school cliildren in its custody).

See e.g., the comments of Lord Mustill in White v. Jones. [1995] 2 А.C. 207 (H.L.) at 291: "(I]t does not conduce to the orderly development of the law, or to the certainty which practical convenience demands, if duties are simply conjured up as a matter of positive law, to answer the apparent justice of an individual case." 
to the guardians of children - a duty which would not provide a remedy to the children directly.

While there are some potential problems rationalizing Lister $v$. Hesley Hall on the basis of non-delegable duty, an argument can be made that liability for traditional negligence might have been available on the facts of Bazley. ${ }^{190}$ As Gaudron J. pointed out in Lepore: ${ }^{191}$

\begin{abstract}
Ordinarily. if there is a material increase in a risk associaled with an enterprise involving the care of cliildren that is a foresecable risk and, thus, it is the personal ... duty of those who run that enterprise to take reasonable care to prevent that risk eventuating...
\end{abstract}

\begin{abstract}
And if abuse occurs in circumstances in which an employec has scized an opportunity which could have been obviated by the use of reasonable care, the employer should be held directly liable.
\end{abstract}

\begin{abstract}
A residential institution or authority that does not lake reasonable steps to institute a system such that its employees do not come into personal contact with a child or oller vulnerable person unless supervised or accompanied by another adult should be leeld direclly liable in megligence if abuse occurs in a situation in which there is neither supervision nor an accompanying adult. Further. it seems almost certain that, on that basis, there would be no different result in factually similar cases from those arrived at in Bazley and Lister [v. Hesley Hall Lid.]. So, 100, on that basis, it would be a breach of a personal ... duty of care resulting in direct liability to allow an employec to share a bedroom with a child entrusted to his care, as was the case in Troman [v. North Yorkshire C.C.]. ${ }^{192}$
\end{abstract}

Thus, the indemnification theory of vicarious liability can account for the classic cases, such as Lloyd and Morris on the basis that, properly understood, they are examples of personal rather than vicarious liability. ${ }^{193}$ Likewise, the modern cases such as Bazley and Lister v. Hesley Hall do not conflict with the theory herein proposed for one of the following two reasons: either they are wrongly decided and hence are not a part of the law that needs justification (as held by the High Court of Australia in Lepore); or they too are examples of personal fault in the form of breach of non-delegable duty or a traditional duty of care.

In fact a determination of personal liability was never made in Bazley sinee both parties fought the case on the assumption that the lioundation wis not in fact negligent: see Bazley, supra note 23 at para. 5 Such a determination, however, was made by the trial judge in lister who found the defendant company not negligent in their care of the plaintifl's: see lister v. Ilesley Hall, stupra note 6 at para. 221. Supra note 5 at paras. 123-25. For a similar view, see Shcila Wildeman, "Vicarious Liability for Sexual Assault: The Two New Tests for Scope of Employment in B.(P.A.) v. Curry and T.(G.) v. Griffiths" (1998) 7 Dal. J. Leg. Stud. I at 86-87 where she argues: "[I]t may be argued that the proper limits upon and extension of employer liability for employec sexual assault is more adequately addressed not through attention to the employee's proper role but to the employer's proper duty, posed either under an analysis of the standard of carc in negligence, or in terons of a liduciary ... duty." [1999] L.G.R. 584 (C.A.).

13) See e.g. Dubai, supra nole 49 at paras. 27-29. Lord Nicholls of Birketuhend:

In turning to decisions coneerned with dislinnest conduct I leave aside cases where a tirm or employer undertakes a responsibility to a third party and then entrusts the disclarge of that responsibility to the dishonest partner or agent... I also leave aside cases where the wronged party is defrauded by an employee acting within the scope of his apparent authority... Nor need $l$ enter upon the debale whether either of these two lypes of case is strictly to be regarded as vicarious liability at all.

See also Plains Engineering l.dd v. Barnes.Security Services l.td (1987). 43 C.C.L.T. 129 (Alta. Q.B.). 


\section{Casual Delegation}

Another possible criticism which might be made of the theory herein presented is that it cannot explain the vicarious liability imposed in situations of casual delegation (also known as vicarious liability for the use of a chattel or for gratuitous agents). This doctrine, which was given the imprimatur of the House of Lords in Morgans $v$. Launchbury, ${ }^{194}$ posits that when $B$ requests that $A$ perform some task which involves use of B's chattel (almost invariably an automobile), ${ }^{195} \mathrm{~B}$ will be vicariously liable for $\mathrm{A}$ 's tort provided that $\mathrm{A}$ 's use was "for the owner's purposes, under delegation of a task or duty." 196 In these situations, B is said to be vicariously liable since $A$ is driving as B's non-contractual "agent" in the course of her agency. As Lord Wilberforce noted in Morgans "'agency' in contexts such as these is merely a concept, the meaning and purpose of which is to say "is vicariously liable." 197 The general view has been that the doctrine is not a derivation from principle but rather has been maintained and extended solely as a means for victims of road accidents to have access to the insurance of the car owner - i.e. to further the policy rationales said to explain vicarious liability. ${ }^{198}$

The difficulty with explaining these cases on the indemnity theory is that the agency is gratuitous and does not depend on a contract. ${ }^{199}$ If this is indeed the case, then it would seem to be impossible to base vicarious liability in these situations on a contractual indemnity. In response to this difficulty, one might make several arguments.

The first of these is to argue that the casual delegation cases are explicable on another basis of liability. This is the tack taken in earlier editions of Bowstead \& Reynolds on Agency which attempted to explain many of these cases as being based on personal fault. ${ }^{200} \mathrm{As}$ the

[1973] A.C. 127 (H.L.) [Morgams].

The doctrine was said to be founded in cases dealing with horse and carriage (see e.g., Whreatley $v$. Patrick (1837), 2 M \& W 650, I50 E.R. 917: Chandler v. Broughton (1832), I Cr. \& M 29, I49 E.R. 301) and has been applicd to boats (sce "Theima" (Owmers) v. University College School, [1953] 2 Lloyd's Rep. 613; Pawlak v. Dowcetie. [1985] 2 W.W.R. 588 (B.C.S.C.) at 597-601) and planes (sce Rand v. Bomac Construction L.td. (1988), 55 D.L.R. (411) 467 (Sask. C. A.) (where the claim failed on the facts)). Some courts have even applied the doctrine in situations where no chattel is involved: $S v$. Attorney-General. [2003] 3 N.Z.L.R. 450 (C.A.) (holding the government vicariously liable for the badfaith tort of volunteer foster parents).

1.x. Morgans, supra note 194 at 135. 1.ord Wilberforec. See also the speech of Lord Cross at 144 (cited below) and Lord Salmon at 149. Hence mere permission to use the chattel is not enough to ground vicarious liability: Morgans: Carberny v. Davies. supra note 101.

Morgans, ibid. at 135 .

See e.g. Atiyah, supra note 10 at 134-35: Rogers. Winfield and Jolowicz, supra note 4 at 727; Fleming. supra note 20 at 430; Fridman, Torts in Canada, supra note 10 at 288-89; Markesinis, Markesinis and Deakin, supra note 12 at 582: Lunney \& Oliphant. supra note 185 at 791-92. But see McHugh J. in Scott v. Davis, [2000] 175 A.L.R. 217. [2000] HCA 52 at para. 120 [Scott] who argued forcefully that "[t]he 'motor car' cases are not the product of unprincipled, social engineering on the pan of the common law judges. No doubt the true basis of those decisions has emerged only slowly. But that is often the way of the common law."

As Lord Cross notes in Morgans, supra note 194 int 144: "The owner of the chatlel will be liable if the user of it was using it as his servant or his agent... As [the cases] ... show, the user need not be in pursuance of a contract. It is enough if the clialtel is being used at the relevant time in pursuance of a request made by the owner to which the user has acceded." See also Lord Pearson at 141: "I think there has to be an acceptance by the agent of a mandate from the principal, though neither the acceplance nor the mandate has to be formally expressed or legally binding."

Sec e.g. Reynolds, Bow stead \& Reymolds, supra note 10. 
authors argued: "[T]he best explanation of these cases may in fact be simply that there is a breach of a duty personal to the owner of taking care in managing the car when it is being used for his own purposes, which duty he cannot avoid by delegating the task of driving to another." ${ }^{201}$ While this theory has some plausibility, it is a problematic explanation of the doctrine enunciated in Morgans for a number of reasons. First, it does not explain why there should be a non-delegable duty in relation to motor cars. What is special about motor cars that there should be such a special duty? Second, it does not really explain why the nondelegable duty is limited to situations where the car is being used for the owner's purposes as required by Morgans. For example, if the reason that there should be a non-delegable duty is that because cars are inherently dangerous ${ }^{202}$ then this rationale should apply equally to other situations where the owner gives permission to another to use the vehicle. Thirdly, the judgments in Morgans are phrased in the broad terms of agency as opposed to the narrower grounds of motor cars, ${ }^{203}$ so a non-delegable duty analysis of Morgans would have to apply to situations far removed from dangerous vehicles to include the use of any chattel. ${ }^{204}$ For these reasons, the theory offered in earlier editions of Bowstead \& Reynolds on Agency, did not ultimately offer a satisfactory account of the casual delegation case law. ${ }^{205}$

A second more promising argument is that there is no conflict with the indemnification theory since the casual delegation doctrine is wrong and hence is not in need of justification. That this may be the course to be taken is evidenced by the doubts that have repeatedly been expressed about this "rather mysterious backwater of the law of tort" ${ }^{206}$ which "fits easily into no existing legal category" ${ }^{207}$ and that is therefore "sui generis" 208 or a "legal fiction."209 More importantly, in the recent case of Scott v. Davis, ${ }^{210}$ the High Court of Australia indicated that the doctrine was mistaken and they refused to extend it to cover any chattels other than motor vehicles. As Glesson C.J. commented in response to the suggestion that Australia should follow Morgans v. Launchbury to its logical conclusion:

I am unable to accept that there is a principle of such width. There are a number of objections to it. First. as the reasons of Gummow J. demonstrate. it has no adequate foundation in authority. ${ }^{211}$ Secondly, it is

\section{Jbid. at 509.}

See Honeywill \& Stein, supra note 95. which posited a link between non-delegable duties and extrahazardous work. This decision was doubted as correctly stating the common law in Stevens v. Brodribb Sawmilling (1986), 160 C.L.R. 16 (H.C.A.).

For a similar view, see Rogers, Winfield and Jolowice, supra note 4 at 729; Scoll, supra note 198 at para. 107, McHugh J.

See Moynihan v. Moynihan. [1975] I.R. 192, where the Supreme Court held the owner of leapot vicariously liable for the negligence of her relative in pouring tea.

The newest edition now states that the "cases do not link to agency, at least in the central sense of that word" and that therefore "further details should be sought in works on tort." See Reynolds, Bowstead \& Reynolds, supra note 10 at 427.

F.M.B. Reynolds, "Casual Delegalion" (200I) II 7 Law Q. Rev. 180 at 180.

Rogers, Winfield and Jolowice, supra note 4 at 727.

Dugdale, Clerk \& Lindsell. supra note 10 at 260.

Peter Handford. "Trimming the Wings of Vicarious I.jability" (2001) 9 Tort L. Rev. 97 at 100.

Scort, supra note 198.

In his reasons in Scott, ibid. at para. 267. Gummow J. concluded after an extensive historical analysis "that the 19th century cases relicd upon here [such as Wheatley v. Patrick and Chandler v. Broughton] do not support the principles said by the appellants to be derived from them. Rather, the outcome in those cases to a significant degree was dictated by the common law system of pleading under the Hilary Term Rules. There can be no other proper understanding of them." Likewise. he commented at para. 
impossible to reconcile with the general rule that a person is not vicariously liable for the negligence of an independent contractor. ${ }^{212}$ An independent contractor may be using an article at another's request and for the other's purposes, but the other is not ordinarily responsible for the contractor's negligence. Thirdly, the eriterion of application of the principle is ill-defined and likely to be capricious in its operation. There are many circumstances, in which the owner or bailec of a chattel may request or permit another person to use or operate it. which do not yield readily to classification according to whether a purpose of the owner or bailee is being served. The difficulties which have been experienced in deciding whether a motor car, available for the use of a number of family members, is. on a paricular occasion, being used for a purpose of the owner, illustrate the point. The unsuccessful attempt to develop a special doctrine for the family car is a reflection of those difficulties. In a social setting. judgments formed on the basis of assigning purposes can be artificial and contrived. 213

The tenor of the majority judgments makes it clear that had the High Court been asked to excise the doctrine from Australian law it would have, but that it refrained from doing so solely on the basis that neither party had put into issue the merits of the driving case of Soblusky v. Egan ${ }^{214}$ which had imported the doctrine into Australia. ${ }^{21 "}$ If the High Court is correct, then there is no conflict with the indemnification theory since there is no, and should be no, doctrine of casual delegation. While this is a satisfactory solution to the supposed incongruence, some might feel some residual hesitation in accepting the indemnification model of vicarious liability if it meant that a doctrine supported, in one way or another, by the authority of the Privy Council, ${ }^{216}$ the House of Lords ${ }^{217}$ and various Commonwealth appellate courts ${ }^{218}$ had to be excised from the law.

This brings us to a third possible argument: viz. that the results of the casual delegation cases might be seen to be consistent with the indemnification model of vicarious liability. This argument would recognize that although the agency is in one sense gratuitous in that the "agent" is not to be paid for performing her tasks for the principal, it is in another sense onerous since the principal/employer will have implicitly promised to indemnify the gratuitous agent for harms incurred in the course of her agency. As Earl of Halsbury L.C. argued in Sheffield Corporation v. Barclay:

It is a general principle of law when an act is done by one person at the request of another which act is not in itself manifestly tortious to the knowledge of the person doing it. and such act turns out to be injurious to the

The remarkable result [of the misunderstanding of these cases] was that the notion of "control" - used on a pleading point to show that uncontroverted evidence could support a controverted, but unassailable. allegation - had become sufficient to impute prima facie liability to the owner of a vehicle that was present in it. Thereafter, Samson v. Aitchison [infra, note 216] was added to the footnote supporting the passage in successive editions of Salmond - an instance of self-referential amplification of a point of law.

For a similar view, see B.J. Brooke-Smith. "Liability tor the Negligence of Another - Servant or Agent?" (1954) 70 Law Q. Rev. 253 at 260. Fleming. supra note 20 at 430.

Scoll, supra note 198 at para. 18 (footnotes added]

(1960) 103 C.L.R. 21 S (II.C.A.) [Soblusky].

For a similar view, sec Handiord, supra note 209 at 98. Gueman v. Mfetall. [2004] NSWCA 378 at paras. 53-56.

Samson v. Aitchuson, [1912] A.C 844 (P.C); Trust Co Led. v. de Silva, [1956] I W.L.R. 376 (P.C.). Rambarran v. Gurrucharran. [1970] I All L.R. 749 (P ( )

Morgans, supra note 194.

Sec e.g., Soblusky, supra note 214; Manawatu County v. Rowe. [1956] N.Z.L.R. 78 (C.A.); Gramak

Lid. v. O'Connor (1974). I O.R. (2d) 505 (C.A.). 
rights of a third party, the person doing it is entilled to an indemnity from him who requested that il shoukd be done. ${ }^{219}$

Of course this principle would not apply fully to the facts of the casual delegation cases since Lord Halsbury was dealing with situations where the person indemnified had no choice but to commit the act requested, and in these situations the gratuitous agent was free to decline. However, this statement of the law does raise the possibility of an indemnity being implied given the right combination of facts.

What then would be the facts where an indemnity would plausibly have been agreed to by the parties had they turned their minds to the question? Once it has been concluded that the "gratuitous agent" is not an independent contractor trading at her own risk (i.e. herself a principal), ${ }^{220}$ it seems that at least two factors would be relevant in deciding whether to imply a promise to indemnify. The first is the difficulty and length of the task that the agent was requested to perform and the second is the presence or absence of insurance. One could argue that if $A$ agrees to do a particularly onerous favour for $B$ which carries with it some characteristic risks and $B$ has the necessary insurance coverage, it seems likely that $B$ would promise to indemnify $A$ when such a harm comes to fruition. In any event, the implication of such a promise is consistent with the idea of friendship which is at the heart of many of the cases.

If this is correct, then many of the leading cases of casual delegation can be explained in a way that is consistent with the indemnification model of vicarious liability. Of course, cases such as Morgans, Hewitt v. Bonvin ${ }^{221}$ and Rambarran v. Gurrucharran ${ }^{222}$ are naturally consistent since they denied liability on the basis that no request to do the act had been made by the person sought to be made vicariously liable. Likewise, the decision in Scott as to no vicarious liability is also explained on the basis that the putative employer did not have insurance to cover accidents such as occurred and therefore it would be unlikely for there to be an implicit promise of indemnity. ${ }^{223}$ But even cases where liability has been imposed on the basis of gratuitous agency are also arguably consistent. Take for example Ormrod $v$. Crosville Motor Services Lid. ${ }^{224}$ In that case, the defendant asked his friend to drive the defendant's car from Birkenhead to Monte Carlo, the plan being that once the car had arrived in Monte Carlo, the friends would go vacationing together in Switzerland. Soon after the car had left Birkenhead, however, it was involved in an accident through the negligence of the friend. The English Court of Appeal held that the car was being driven by the friend on

[1905] A.C. 392 at 397: principle affirmed in Yeung Kai Yung v. Hong Kong and Shanghar Banking Corporation, [1981] A.C. 787 (P.C.).

3:) See Norton v. Canadian Pacific Steamships, [1961] 2 All E.R. 785 (C. A.) (where the claim based on causal delegation failed due 10 independent nature of the licensed porters who were analogous to independent contractors); K.L.B. supra note 188 (government not vicariously liable for foster parents since they would not be perceived as representing the government and are therefore ak in to independent contractors). See also the judgment of Mcl lugh J. in Scoll, supra note 198 at paras. 23,70 and 110 , who emphasizes this limitation.

$\because \quad[1940]$ I K.B. 188 (C.A.).

::: Supra note 216.

$\because \quad$ Nor was Davis required by law to have such insurance, see Handford, supra note 209 at 99: Lunney \& Oliphant, supra note 185 at 792.

2 Supra note 101. See also Carberny vavies. supra note 101, which is also explicable using the methodology herein proposed 
behalf of the defendant and at his request and therefore that the defendant was vicariously liable for the negligence. If we apply the methodology posited above, the implication of an indemnity on the facts of Ormrod seems plausibly justified for two reasons: first, the trip was rather long with the attendant risk that the friend might be involved in a collision; and second, it is quite likely that the defendant, as owner of the car, was covered by insurance for just these sorts of risks. ${ }^{225}$ Now, of course, not every case on casual delegation is explicable on these dual grounds ${ }^{226}$ but as McHugh J., himself a leading proponent of casual agency reasoning, noted in Scott: "Not all the "motor car' cases have been correctly decided."227

Thus the casual delegation cases do not conflict with the theory of vicarious liability outlined in Part III of the article. They are either wrongly decided and hence are not a part of the law that needs justification, or they can more or less be accommodated by the theory if one accepts that in certain circumstances the parties have implicitly agreed to indemnification.

\section{Conci.usion}

In her judgment in Lepore, Gaudron J. noted that the law has yet to offer a "comprehensive jurisprudential basis for the imposition of ... vicarious liability" that is consistent with its central features. ${ }^{228}$ In response to this vacuity, this article has proposed the indemnification theory of vicarious liability. Stated briefly, this theory posits that the only compelling justification for the doctrine is the employer's implied promise to indemnify her employees for harms (including legal liability) suffered in the course of their employment. This claim was defended in four parts. In Parts I and II, the article detailed the central features of vicarious liability and outlined why the leading rationales of control, compensation, deterrence, loss-spreading, enterprise liability and mixed policy fail to adequately account for these rules. In Part III, the article established how the indemnification

As Handford, supra note 209 at 99 notes, it has been compulsory since 1930 for English car owners to insure against third-party liability.

23. The case which presents the most difficulty is that Samson v. Aitchison, sippra nole 216 . In that case a widow was thinking of purchasing a car from the defendant. She asked lier son, a chauffeur. 10 examine the car. The defendant then took the son and the widow for a test drive to prove the merits of the vehicle. At some point during the drive. the defendant suggested that the son should drive the car himself. Soon after taking the wheel, the car struck and injured the plaintiff through the son's negligence. The Privy Council found the defendant to be vicariously liable for the son's driving on the basis of the defendant's control of the vehicle. As Lord Atkinson argued at 850: "[1] $f$ the control of the car was not abandoned, then it is a matter of indifference whether [the son]. while driving the car, be styled the agent or the servant of the [defendant] in performing that particular act, since it is the retention of the control which the [defendant] would have in either case that makes him responsible for the negligence which caused the injury." Given that the son was a chauffeur, that the task delegated was nol particularly onerous and that it is far from clear whether the defendant was insured, the decision could not likely be justificd on the methodology hetein suggested. Other cast's in which "vicarious" liability was imposed, but which are inexplicuble as instances of indemnilication. are straightforwardly explained on other grounds. For example, the liahility of the car owner/principat in Trust Co. Lid, v. De Silva, supra note 216 is explicable on the basis that the principal contracted to provide the injured defendant with safe passage. Likewise, Barnord v. Sully (1931), 47 \%.L. R $\$ 57$ is merely a case about evidence as opposed to substantiate law, the court linding that when a car owner/passenger refused to testify as to the legal status of the driver, a judge or jury could draw the adverse inference that the driver was an employeefagent of the owner (i.e. was a person entitled to an indemnily). 
theory can account for the traditional limitations imposed on vicarious liability. Part IV then dealt with possible objections to the theory and demonstrated: (1) that no leading cases stand in the way of accepting the indemnification model; and (2) that acceptance of this theory of vicarious liability does not necessarily mean abolition of the doctrine through contractual stipulation. If this article has succeeded, vicarious liability will no longer be an unexplained mystery of tort law which seemingly contradicts the pervasive regime of fault, but rather it will be seen as an application of the contractual concepts of subrogation and indemnity to the particular relationship between employee, employer and tort victim. If this is right, then it also follows that the common law doctrine of vicarious liability is explicable, despite repeated claims to the contrary, ${ }^{229}$ as a coherent manifestation of the principles of corrective justice. of Appeal argues that "it is impossible to fit [vicarious liability and non-delegable duty] ... within the correlative framework of the corrective justice model." 